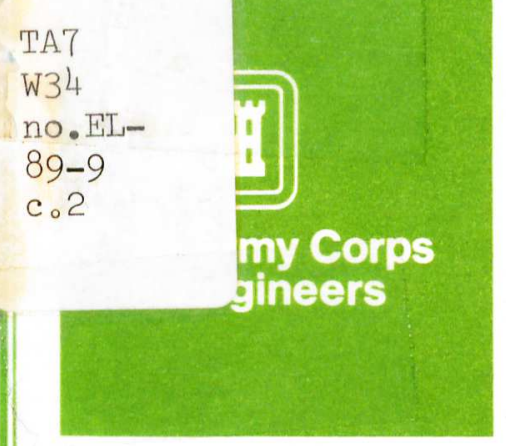

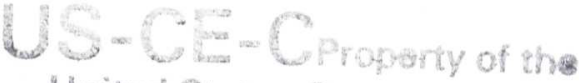

Unitad Statos Govdrnmont

TECHNICAL REPORT EL-89-9

\title{
FISHERIES INVESTIGATION ON THE LOWER WHITE RIVER ARKANSAS
}

\author{
by
}

John A. Baker, Richard L. Kasul

K. Jack Killgore, Larry G. Sanders

Environmental Laboratory

DEPARTMENT OF THE ARMY

Waterways Experiment Station, Corps of Engineers

PO Box 631, Vicksburg, Mississippi 39181-0631

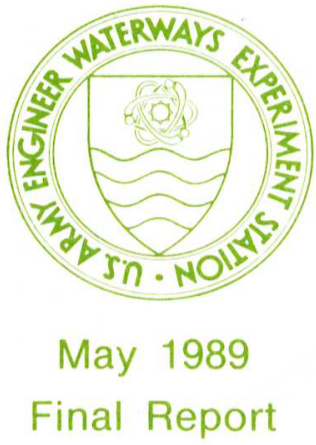

Approved For Public Release; Distribution Unlimited

Library Branch

Technical Information Center

U.S. Army Engineer Waterways Exporiment Station

Vicksburg Mississippi

Prepared for US Army Engineer District, Little Rock Little Rock, Arkansas 72203-0867 
Destroy this report when no longer needed. Do not return it to the originator.

The findings in this report are not to be construed as an official Department of the Army position unless so designated by other authorized documents.

\footnotetext{
The contents of this report are not to be used for advertising, publication, or promotional purposes. Citation of trade names does not constitute an official endorsement or approval of the use of such commercial products.
}

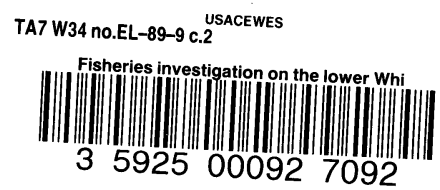


Unclassified

SECURITY CLASSIFICATION OF THIS PAGE

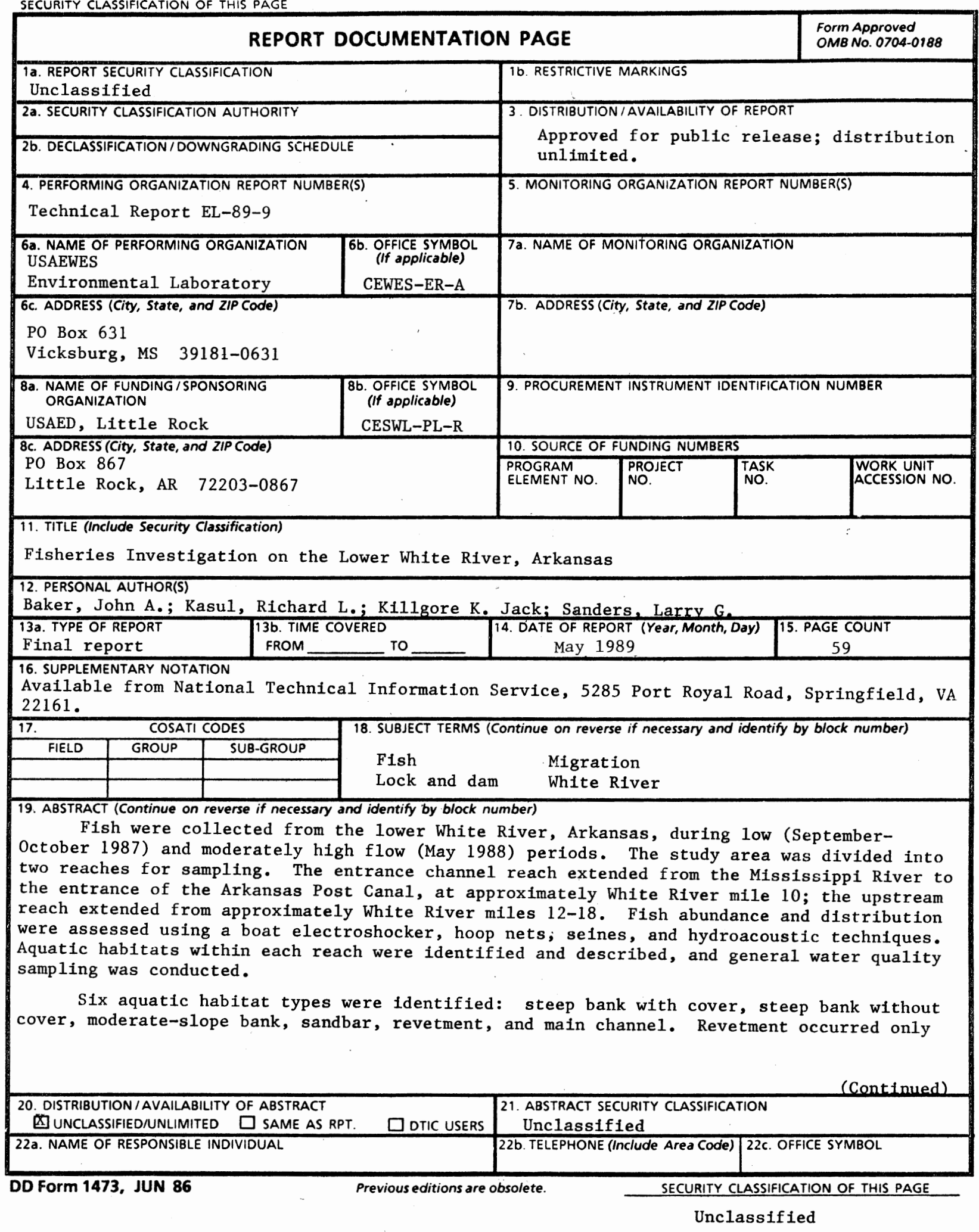


Unclassified

BECURITY CLABSIFICATION OF THIS PAOR

19. ABSTRACT (Continued).

in the entrance channel reach; other habitats occurred throughout the study area. During both collections, water quality was similar to that of other nearby large rivers.

Overall, 58 fish species were collected by electroshocking, hoop netting, and seining. These species, plus five reported in earlier studies but not taken during this . study, bring the known lower White River fish fauna to 63 species. This 1ist probably includes most species that typically inhabit the study area. Although differences in relative abundance were observed for some species, the fish assemblages of the two reaches were quite similar overall. Habitats differed in species composition and relative abundances, but pattern of differences depended on gear type, reach, and sampling period. Slightly more species, and nearly twice as many fish, were collected during the moderately high flow period compared with the low flow period. During the moderately high flow period, fish were also more abundant in the entrance channel reach than upstream. Condition factors for five of six species were higher in the entrance channel reach; only values for freshwater drum were significantly higher, however.

Relative densities of fish detected by hydroacoustics were significantly higher during the moderately high flow period than during the low flow period. Within each period, both reaches had similar relative densities. Estimated acoustic fish sizes averaged larger in the upstream reach during both sampling periods; slightly larger average sizes were detected during the low flow period.

The resident fish populations of the entrance channel reach of the lower White River do not appear to have been changed, relative to the upstream reach, by present navigationrelated activities (barge traffic, dredging, revetment placement). The placement of a dam effective only at relatively low flows is not likely to cause substantive changes in these populations. However, a number of species may migrate into the White River system from the Mississippi River for spawning. Although this study did not adequately assess the abundance and timing of migration of these species, sufficient information is available from the 1iterature to address the potential impacts of the project on many of these migratory species. 
This report presents the results of a fisheries investigation on approximately the lower 18 river miles of the White River, Arkansas. The report compares the fish populations in the entrance channel reach of the McClellanKerr Arkansas River Navigation System, where large-scale navigation-related activities occur, with those farther upstream during low and moderately high flow periods. Data were collected during September-October 1987 and May 1988 by individuals from the Fisheries Team, Aquatic Habitat Group (AHG), Environmental Laboratory (EL), US Army Engineer Waterways Experiment Station (WES), Vicksburg, MS. Mr. Richard E. Coleman of WES and Dr. Raymond P. Morgan of the University of Maryland assisted in the collection of data.

The report was prepared by Messrs. John A. Baker, Richard L. Kasul, K. Jack Killgore, and Larry G. Sanders, AHG, and was edited by Ms. Lee T. Byrne, Information Technology Laboratory, WES. The investigation was managed by the EL under the direct supervision of Mr. Edwin A. Theriot, Chief, AHG, and Dr. Conrad J. Kirby, Chief, Environmental Research Division, and under the general supervision of $\mathrm{Dr}$. John Harrison, Chief, EL. The study was sponsored by the Planning Division, US Army Engineer District (USAED), Little Rock. Technical Monitor at USAED, Little Rock, was Mr. Chris Hicklin.

COL Dwayne G. Lee, EN, is the Commander and Director of WES.

Dr. Robert W. Whalin is the Technical Director.

This report should be cited as follows:

Baker, John A., Kasu1, Richard L., Killgore, K. Jack, and Sanders, Larry G. 1989. "Fisheries Investigation on the Lower White River, Arkansas," Technical Report EL-89-9, prepared for US Army Engineer District, Little Rock, by the US Army Engineer Waterways Experiment Station, Vicksburg, MS. 
PREFACE ...........................................

CONVERSION FACTORS, NON-SI TO SI (METRIC)

UNITS OF MEASUREMENT. .....................................

PART I $\quad$ INTRODUCTION .................................. 4

Background ....................................... 4

Objectives........................................

PART II $\quad$ STUDY AREA.................................. 6

Genera1........................................... 6

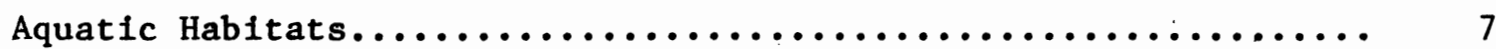

PART III: METHODS .........................................10

Sampling Periods...................................... 10

Physical and Chemical................................. 10

Fish Collections..................................... 10

Hydroacoustics....................................... 12

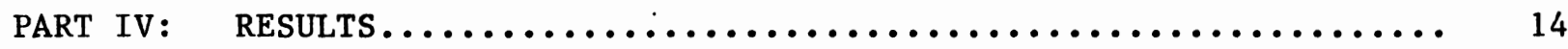

Physical Characteristics and Water Quality.................. 14

Fish............................................. 14

Hydroacoustics....................................... 19

PART $v: \quad$ DISCUSSION .................................. 22

Species Composition.................................... 22

Potential Impacts of Dam on Resident Species................ 23

Potential Impacts of Dam on Fish Migration.................. 24

PART VI: CONCLUSIONS .................................. 27

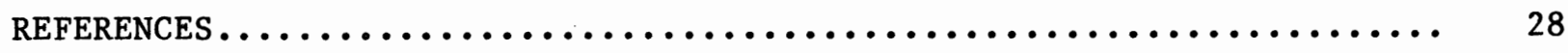

TABLES $1-21$ 


\section{CONVERSION FACTORS, NON-SI TO SI (METRIC) \\ UNITS OF MEASUREMENT}

\begin{tabular}{|c|c|c|}
\hline Multiply & By & To Obtain \\
\hline cubic feet & 0.02831685 & cubic metres \\
\hline degrees (angle) & 0.01745329 & radians \\
\hline feet & 0.3048 & metres \\
\hline inches & 25.4 & millimetres \\
\hline miles (US statute) & 1.609347 & kilometres \\
\hline
\end{tabular}


FISHERIES INVESTIGATION ON THE LOWER WHITE RIVER, ARKANSAS

PART I: INTRODUCTION

\section{$\underline{\text { Background }}$}

1. The lower 10 miles* of the White River in east-central Arkansas form the entrance channel to the McClellan-Kerr Arkansas River Navigation System. The Arkansas Post Canal connects the lower segment of the Arkansas River with the entrance channe1. Depths within the Arkansas River and the Post Canal are controlled by a series of locks and dams. The entrance channel, however, is subject to the relatively less controlled flows of the lower White River. Very low discharges in the White River and low stages on the Mississippi River typically occur in the late summer and fall, and as a result, a navigation channel of sufficient width and depth is not always available without extensive dredging.

2. One option being considered for alleviating the low-water navigation problems on the lower White River is the construction of a lock and dam in the vicinity of river mile (RM) 0.5 , just upstream from the confluence with the Mississippi River. The dam would have an appreciable effect on river current speeds, depths, and water quality only during the extreme low-water period of the year. At this time, depths would increase approximately $3 \mathrm{ft}$ in the affected reach, and current speeds would decline to near zero.

3. One concern is the effect this project might have on the fishery resource in the lower White River. Historical information suggests that the lower White River sustains a productive and valuable commercial fishery. However, there is little documentation of fish of the lower White River and none at all for the project area. Only two collections oriented toward larger, riverine fish are known: a rotenone study in the fall of 1971 in the vicinity of RM 55 (Arkansas Game and Fish Commission, unpublished data) and an electroshocking study near RM 15 and 67 (Gulf South Research Institute 1973). These studies documented the occurrence of only 27 and 21 species of fish,

* A table of factors for converting non-SI units of measurement to SI (metric) units is presented on page 3. 
respectively (with a total of 34). The US Fish and Wildlife Service (USFWS)

(1987) compiled an environmental inventory for the lower 10 miles of the White River, but they did no additional fish sampling. They concluded that populations of fish in the lower White River were indicative of a well-balanced, productive fishery. Water quality was considered to be good, with no evidence of serious pollution. Researchers at several area universities have made small collections from the river, but these have typically been made only with seines, and the results have not been published.

\section{Objectives}

4. The purpose of this study was to develop a comprehensive baseline fishery data set for the lower White River. Specifically, attempts were made to: (a) compare the overall fish assemblage of the entrance channel reach with that of the relatively unmodified reach immediately upstream, (b) evaluate fish distribution and relative abundance by general habitat type, (c) compare fish species presence and abundance between summer low-flow and spring high-flow periods, and (d) identify potential spring migratory species. In addition, the kinds of aquatic habitat present in each reach were identified and described, and the general water quality conditions at the times of sampling were recorded. 


\section{Genera1}

5. The study area for this investigation was a 17-mile segment of the lower White River immediately upstream from the confluence of the White and Mississippi Rivers (Mississippi River mile 599, White River mile 0). This segment was divided into two study reaches (Figure 1). The entrance channel reach extended from the Arkansas Post Canal to the Mississippi River, a

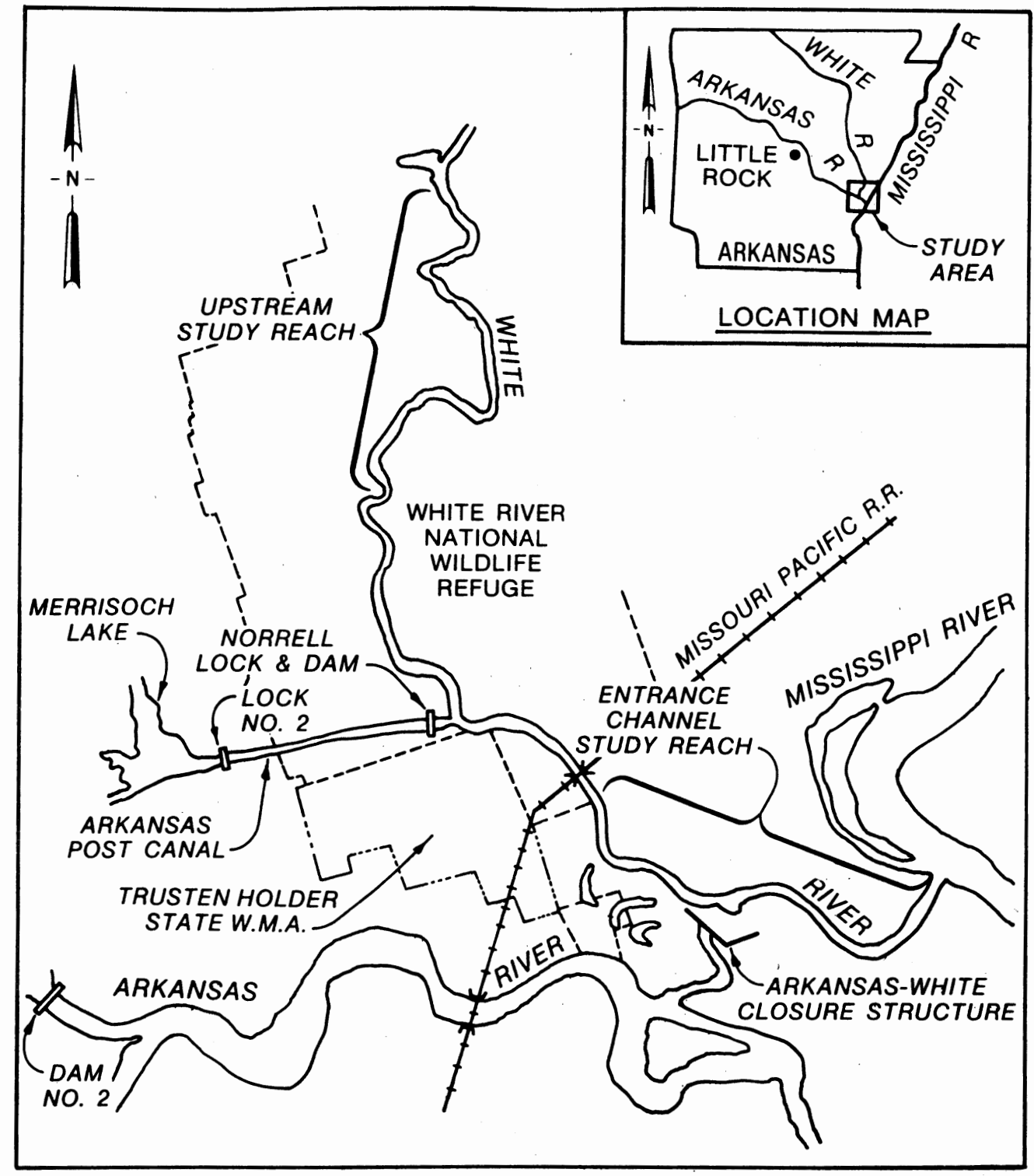

Figure 1. The lower White River study area, showing the entrance channel and upstream reaches 
distance of about $10 \mathrm{RM}$. Within this reach only the downstream-most 6 miles were sampled, because the direct impacts of the proposed dam on depth and current velocity are unlikely to extend beyond this distance. The upstream reach began approximately 2 RM above the entrance to the Post Canal and continued upstream for a distance of about 6 miles. While a navigation channel is maintained upstream as far as Newport, AR, most commercial river traffic moves through only the entrance channel reach. In addition, the entrance channel reach is subjected to dredging during most years.

6. River stage within the study area is largely determined by the Mississippi River during much of the year (US Army Engineer District (USAED), Little Rock 1987). When the Mississippi stage is relatively high, the stage on the lower White River is raised, which will decrease the current velocity if the flow remains constant. Low stages on the Mississippi allow flows in the lower White River to pass relatively unimpeded.

\section{Aquatic Habitats}

7. Aquatic habitats were visually surveyed in both reaches prior to the first sampling. Six types were identified, five occurring in both reaches and one occurring only in the entrance channel reach. The general characteristics of these habitats, which are similar to those of their counterparts within the adjacent Mississippi River (Cobb and Clark 1981), are described in the following paragraphs.

$\underline{\text { Sandbar }}$

8. This habitat consisted of the relatively shallow, gently sloping areas ( $<20 \mathrm{deg}$ ) found on the inside of many river bends. The channelward edge of this habitat type was defined as the 9-ft low-flow contour (the minimum depth of the navigation channel). Depths ranged from a few inches to $9 \mathrm{ft}$ during low-flow conditions and to over $15 \mathrm{ft}$ during the high-flow period. The substrate consisted either of clean sand or sand overlaid with a light to moderate silt-clay layer. Current speeds were near zero alongshore and increased gradually toward the main channel; maximum low-flow period currents were about $2 \mathrm{ft} / \mathrm{sec}$, while during the high-flow period, observed current speeds often exceeded $3 \mathrm{ft} / \mathrm{sec}$. 
Steep bank with cover

9. This aquatic habitat type usually occurred on the outside of river bends, along eroding banks. This habitat comprised a relatively narrow strip of river only about $50 \mathrm{ft}$ wide, because the deep, swift main channel ran very close to the bank in such areas. Bank slope was nearly vertical, and depths ranged from about 5 to $20 \mathrm{ft}$ at low flow and from 10 to $25 \mathrm{ft}$ at high flow. Substrates were most often consolidated clay, although areas of sand or mud occurred frequently. Considerable amounts of fallen trees and brush (= cover) were present in the water. Current speeds during the fall low-flow period ranged from 1 to $2 \mathrm{ft} / \mathrm{sec}$; during the spring high-flow period currents were higher, ranging from about 3 to $6 \mathrm{ft} / \mathrm{sec}$.

Steep bank, no cover

10. This habitat was similar in all respects to steep banks with cover except that very little brush or trees were present.

Moderate-slope bank

11. As the name implies, one of the characteristics distinguishing this habitat from the steep banks and the sandbar was the degree of bank slope, which ranged from about 30 to $50 \mathrm{deg}$. Substrate was clay overlaid with a relatively thick mud layer. Currents were similar to those of the sandbar habitat, grading from zero nearshore to speeds characteristic of the main channel offshore. Also like the sandbars, depth tended to be relatively shallow at the shoreline and to increase steadily toward the main channel. The channelward edge of this habitat was defined as the 9-ft low-water contour. Very little cover was present in this habitat.

Revetment

12. In contrast to the four habitats described above, revetment habitat was found only within the entrance channel reach of the study area. Revetments consisted of rock riprap placed over banks graded to about a 30-deg slope. As with the steep banks, this habitat consisted of a fairly narrow strip of water paralleling the riprapped shoreline. Depths were up to $20 \mathrm{ft}$ during the low-water period, and they approached $30 \mathrm{ft}$ during the high-water period. Currents were quite variable, ranging from zero to over $5 \mathrm{ft} / \mathrm{sec}$, depending upon distance from shore and longitudinal position along the revetment. Very little submerged cover (other than the crevices among the rocks) was noted in this habitat. 


\section{Main channel}

13. This habitat consisted of all portions of the river within the 9-ft minimum depth contours defining the navigation channel. Along the steep banks and the revetment, the main channel habitat ended at the outer limit of these habitats. Depths ranged from 9 to $45 \mathrm{ft}$ in the main channel during fall and from about 15 to $50 \mathrm{ft}$ during spring. Currents were 1.5 to $3.0 \mathrm{ft} / \mathrm{sec}$ in the fall and 3 to $6 \mathrm{ft} / \mathrm{sec}$ in the spring. 
PART III: METHODS

\section{Sampling Periods}

14. Two general seasons were selected by the US Army Engineer Waterways Experiment Station (WES) and USAED, Little Rock, for sampling, one to represent low flows typical of late summer and fall and one to represent the moderate to high flows usually experienced during late spring. Fall sampling occurred during the weeks of 21-25 September and 28 September-2 October 1987. The spring sampling took place during 2-6 May 1988.

\section{Physical and Chemical}

15. During each sampling period, discharge was estimated by determining depth and current speed at several points along a cross-channel transect within the entrance channel reach. Depths were determined with an electronic Fathometer and current speeds with a Marsh-McBirney electronic meter; distance from the shoreline was measured using a hand-held rangefinder. Average current speed and cross-sectional area were calculated independently for segments of the transect within which depth and current speed were judged to be relatively consistent. Total river discharge was determined by summing the estimated discharges for the segments. What were judged to be typical current speeds and depths within each habitat were estimated during collection of electroshocking samples (see paragraphs 20-24).

16. In the fall, water quality was assessed at several points along the cross-channel transect described above; in the spring, water quality was assessed at only a single midchannel station. Measurements of water temperature, $\mathrm{pH}$, dissolved oxygen concentration, and conductivity were made using a Hydrolab 8000 in situ unit. Turbidity was determined using a Hach field turbidimeter.

\section{Fish Collections}

17. Fish were collected from the five bank habitats using hoop nets, seines, and a boat-mounted electroshocker. The main channel could not be 
effectively sampled with these gears because of its high current speeds and great depths.

18. Hoop nets were $3 \mathrm{ft}$ in diameter and $15 \mathrm{ft}$ long and had 1-in.-square mesh throughout. Within each reach, single, unbaited nets were placed at six randomly selected sites within each habitat type. Nets were fished for four consecutive 24-hr periods, with the catch being removed and tabulated every $24 \mathrm{hr}$. Thus, maximum sample size for any single habitat was 24 net-days per sampling period; however, loss of nets (possibly because of navigation traffic, swift currents, or drifting debris) caused actual sample sizes to be lower in some instances, especially during the spring high-water sampling.

19. A 30- by 8-ft, 3/16-in. mesh straight seine was used to sample the sandbar and moderate-slope bank habitats during the fall low-water period. In the spring, the high-water level and fast current speeds prevented sampling with seines along the moderate-slope bank habitat so that only the sandbars were sampled. Six 50-ft hauls were made in each habitat available for sampling in each reach.

20. Electroshocking was conducted from an 18-ft aluminum boat having two bow-mounted anodes. A Coffelt Model VVP-15 electroshocker was operated in pulsed-d-c mode so that an output of 325 to $400 \mathrm{v}$ and 5 to $8 \mathrm{amp}$ was achieved. Two netters stood on the bow and collected all stunned fish. Two separate stretches of bank (replicates) were sampled within each habitat type in each reach in each season. The total amount of time spent in each habitat was approximately proportional to its relative abundance within each reach.

21. In the fall, larger fish collected with hoop nets and the electroshocker were identified, measured (total length), and weighed in the field before being released alive. In the spring, fish were again measured, but weights were not taken. Fish weights vary considerably during spring because of unequal apportionment of energy into reproduction by different sizes, ages, and sexes of fish. Males and females usually differ greatly in length-weight relationship at this time, and fish must often be sacrificed to be accurately sexed. Therefore, only fall-collected fish were used for calculating condition factors. Only species for which sample sizes were judged sufficient were used. If numbers were high, the length-weight relationship was examined separately for the two reaches; otherwise, fish from both reaches were combined. Condition factors were computed according to the formula: $\mathrm{K}=$ weight $\times 10^{5}$ $\div$ length cubed (Ricker 1975). 
22. All fish collected by seine were immediately preserved in 10-percent formalin and identified in the 1ab. Seine-collected specimens were identified and counted, but they were not measured or weighed. Voucher specimens of uncommon species collected by the other gears were also preserved.

23. Catch rates among habitats, reaches, and sampling seasons were compared on the basis of catch per minute with the electroshocker, catch per net-day with the hoop nets, and catch per 50-ft haul with the seine. For tabular presentation of data, numbers of fish captured were adjusted to arbitrary standards of 24 hoop net-days and 25 min of shocking (the most common totals). This adjustment allowed direct comparisons of total catches between reaches and seasons and across habitats.

24. Statistical comparisons were made between seasons and reaches and among habitats, employing analysis of variance (ANOVA) techniques. The analyses were used only as exploratory mechanisms to help interpret observed patterns of species abundance.

\section{Hydroacoustics}

25. Hydroacoustics was used to remotely sample fish in the deeper, open-water habitats of both the entrance channel and upstream reaches. Acoustics effectively sampled fish in the main channel and portions of the shoreline, but it did not sample shallow sandbar habitat or extreme nearbank areas. Thus, areas sampled with hydroacoustics overlapped very little with those sampled by hoop net, seine, and electroshocker, resulting in a more complete assessment of fish distribution and abundance.

26. Hydroacoustic sampling employed a research-grade fishery sonar system for remote detection of fish, using echo return data. The field acquisition system consisted of a Biosonics Model 105 Echosounder operating at $420 \mathrm{kHz}$, a dual-beam transducer with 6/15-deg nominal width, a Biosonics Model 171 Tape Recorder Interface, an Hitachi Oscilloscope, a Sony digitizer and Betamax video recorder, an EPC Model 1600 Chart Recorder, and a Biosonics Chart Recorder Interface. Mobile sampling was conducted from a 21-ft inboard/outboard workboat with the transducer suspended over the port bow about $0.5 \mathrm{~m}$ below the surface of the water. The transducer was mounted inside a stabilizing fin that directed it into a downward position while the boat was moving. 
27. Each reach was acoustically sampled along a set of approximately equally spaced transects running from shore to shore across the channel. Each transect sampled the river cross section with a 6-deg transducer beam, which permitted detection of fish between surface and bottom in a wedge-shaped sampling volume that was approximately $0.5-\mathrm{m}$ wide at a depth of $5 \mathrm{~m}$ and $1.0 \mathrm{~m}$ wide at a depth of $10 \mathrm{~m}$. Echo returns from all sources were recorded on chart paper and also tape recorded for later analysis.

28. An index to fish abundance was computed from counts of fish targets that were digitized from chart recorder echograms. Individual fish detections were first weighted by the inverse of $\mathrm{fish}$ range from the transducer to adjust for the greater sample area at increased depths. Weighted detections were then totaled for each transect, the result weighted by the relative length of the transect measured in digitizer units, and per transect values were then summarized for each river reach and season.

29. The acoustic size of individual fish echoes was computed using a Biosonics Mode1 181 Dual-Beam Processor and associated postprocessing computer programs. The acoustic size (target strength) of individual fish, a measure of the fish's inherent echo-reflecting ability, was calculated in acoustical units called decibels $(\mathrm{dB})$. A noise threshold applied during processing eliminated any targets smaller than about $-58.5 \mathrm{~dB}$ (approximately $2 \mathrm{~cm}$ ). Summary statistics of fish size in decibels were calculated separately for the two reaches and seasons for comparison of fish size distribution characteristics. The amount of incident sound energy echoed back by fish increases with the size of the fish's gas bladder and skeleton; therefore, larger fish tend to produce larger echo returns. A regression relationship predicting fish length from target strength values (Love 1971) was used to provide a rough guide to interpretation of the target strength values. Because target strength is affected by many factors such as species, fish position in the beam, and orientation of the fish in the water, this equation produces only a rough guide to actual fish length. 
Physical Characteristics and Water Quality

30. The Mississippi River was at a relatively low stage during the September 1987 sampling (2.9 to $4.3 \mathrm{ft}$ at Arkansas City). The White River at Clarendon was also low $(8.5$ to $9.2 \mathrm{ft}$ ), and the observed river level during the sampling did not change appreciably. The discharge estimate for the study area at this time was slightly more than 14,000 cfs. During the May 1988 sampling period, gage heights on both rivers were higher. At Arkansas City, the Mississippi River stage was $15.0 \mathrm{ft}$ on 2 May and had fallen to $12.6 \mathrm{ft}$ by 6 May; the Clarendon gage was relatively steady at a high 26.3 to $26.5 \mathrm{ft}$. Under such conditions (moderate, rapidly falling Mississippi River stage and high White River stage), the Mississippi does not impede White River flow, and discharge (estimated 39,600 cfs during spring sampling) and current speeds are high. The observed river level during the sampling dropped about $2.5 \mathrm{ft}$ in response to the change in Mississippi River stage.

31. River widths were approximately 450 to $600 \mathrm{ft}$ in both reaches in the fall, and they were about 550 to $650 \mathrm{ft}$ in the spring. Recordings made during the hydroacoustic sampling indicated that the average thalweg depth in the entrance channel reach was greater than that in the upstream reach (Table 1). The maximum recorded thalweg depth was also greater. These relationships were unchanged between seasons.

32. Water quality measurements showed relatively small differences between the two seasons (Table 1). The readings were fairly typical of large southern US rivers for the respective times of year.

Fish

33. During the study, 58 species were collected (Table 2), the largest such list yet accumulated for the lower White River. The results presented in the following paragraphs are arranged by gear type, since each is effective for a different subset of the overall fish assemblage. As noted in Part III, catches are presented in tables as both actual and adjusted numbers wherever applicable. Adjusted catches reflect differences in the total sampling effort among habitats, making comparisons easier and more accurate. 
34. In the following sections, judgments as to whether a species differed in relative abundance between the two reaches were made following four specific criteria. First, comparisons were made on the basis of adjusted, not raw catches, to account for differences in sampling effort. Second, revetment habitat catches were subtracted from overall totals because revetment occurred in only one reach. Third, since smaller, schooling species (e.g., minnows and shiners, silversides, gizzard and threadfin shad) are generally much more abundant than larger species (e.g., catfishes, buffalos, gars), greater differences in their abundance between reaches were required to consider them real. Finally, consideration was given to the collecting method used, since the three gear types are not equally efficient for all species. Minnows, for example, are not efficiently sampled by boat electroshocker in many habitats, and gars are not effectively captured with seines. Thus, captures of relatively large numbers of such species with a gear type that would usually be considered ineffective were judged especially critically. Electroshocking

35. A total of 34 species was collected by electroshocker during the fall 1987 sampling period, 26 from each reach (Tables 3 and 4). The fish assemblages of the two reaches were similar; 18 of the 34 species were found in both, and 15 of the 16 species found only in one reach were represented by fewer than $10 \mathrm{fish}$. Because these species were rare, their capture could as easily have been due to chance rather than to any intrinsic difference between the reaches. Although the species lists compiled for the reaches were similar, the relative abundances of some common species varied substantially between them. Longnose and shortnose gar, emerald and blacktall shiners, Mississippi silvery minnow, and freshwater drum were considerably more common in the upstream reach, while threadfin shad and bluegill were more abundant in the entrance channel reach. For these latter two species, however, nearly one-half of the individuals were taken in the revetment habitat, which did not occur in the upstream reach.

36. The steep bank with cover habitat yielded the highest number of species in both reaches (Tables 3 and 4 ). The numbers of species collected in each upstream habitat were similar, ranging from only 12 to 16 . In the navigation reach, there was more variation (from 5 to 19 per habitat), and the steep bank without cover and revetment habitats had particularly low numbers of species. Numbers of fish collected were also much higher in the upstream 
reach overall and in three of the four comparable habitats, the sandbar being the only exception.

37. Most species. were collected in numbers too small to suggest meaningful differences in habitat preferences. Gars appeared to avoid the steep bank without cover habitat (Tables 3 and 4), gizzard shad were consistently most abundant in the moderate-slope bank and sandbar habitats, and Mississippi silvery minnow was taken almost only in the sandbar habitat.

38. During the spring 1988 collections, 38 species were taken, 31 in the entrance channel reach (Table 5) and 32 in the upstream reach (Table 6). The assemblages were again similar, with 25 species occurring in both reaches and with all 13 of the species found in only one reach being rare ( 3 or fewer fish in all cases). In contrast to the fall sampling, most species that showed abundance differences were more common in the entrance channel reach, including gizzard and threadfin shad, channel catfish, common carp, bluegill, and freshwater drum. River carpsucker and smallmouth buffalo were more common in the upstream reach.

39. Three of the four comparable habitats yielded higher numbers of species in the upstream reach than in the entrance channel reach; the only exception was the steep bank without cover (Tables 5 and 6). In contrast to the fall collection, the numbers of species among habitats showed most variability in the upstream reach. Adjusted catches were higher overall, and in all habitats, in the entrance channel reach.

40. A number of relatively abundant species in each reach differed in their habitat distributions (Tables 5 and 6 ). Gizzard shad was common along steep banks with no cover in both reaches and also along moderate-slope banks in the upstream reach. Threadfin shad showed a higher catch rate along steep banks with cover and revetments in the entrance channel reach. In the entrance channel reach, common carp was abundant in the moderate-slope bank habitat but did not occur along steep banks without cover. Blacktail shiner was substantially more common in the steep bank without cover habitat in the entrance channel reach and in the sandbar habitat upstream. Freshwater drum was very numerous in the moderate-slope and sandbar habitats in the entrance channel reach and also along the sandbars upstream. Other species, including river carpsucker, Mississippi silvery minnow, and bluegill, suggested patterns of habitat differences, but their moderate numbers made speculations inappropriate. 
41. The ANOVA for electroshocking indicated a strong season effect and also a significant habitat effect (Table 7). Significant interactions existed between season and both reach and habitat. The overall ANOVA interpretation is that season strongly affects overall electroshocking catch rates in the study area (overall catch was about twice as high in spring) and that the effect varies between the two reaches and also to some extent among habitats. This is clearly seen in Tables 8 and 9. Catches were higher in both reaches in spring, but they increased by 350 percent in the entrance channel reach and only 38 percent in the upstream reach. Habitats differed substantially in catch rate, but their rankings varied with season, as suggested by the significant season $X$ habitat interaction (Table 7). Steep banks without cover had the lowest mean catches in the fall (both reaches combined), but they had the highest catches in spring. Ranking of the steep banks with cover changed from second in fall to last in spring. Although revetment catches were not compared statistically with those of the other habitats, they were obviously similar in both seasons (Tables 8 and 9).

Hoop nets

42. During the fall 1987 sampling, 16 species were captured by hoop nets, 13 from the navigation reach (Table 10) and 15 from the upstream reach (Table 11). Twelve of the species were taken in both reaches, and of the four species unique to one reach, only longnose gar was common enough to suggest a real difference. Blue and flathead catfish, white crappie, and freshwater drum were collected in considerably higher numbers in the entrance channel reach. As noted, only longnose gar suggested greater numbers within the upstream reach.

43. Of the species taken in relatively high numbers, only white crappie and freshwater drum indicated possible habitat preferences. Most of the white crappie were captured in the moderate-slope bank and steep bank with cover habitats in the entrance channel reach. Freshwater drum was most abundant along the moderate-slope banks, and to a lesser extent along steep banks without cover, in both reaches (Tables 10 and 11).

44. Numbers of species were not very different among habitats nor between reaches. Numbers of fish taken, however, were greater in the entrance channel reach in every comparable habitat (Tables 10 and 11) and overa11, even without the contribution of the revetment. 
45. During the spring 1988 sampling, 17 species of fish were collected in hoop nets with 14 species being taken in each reach. Of the three species unique to each, none was represented by more than four fish (Tables 12 and 13). Of the six relatively abundant species, five (channel, blue, and flathead catfishes; white crappie; and freshwater drum) had highest adjusted catches in the entrance channel reach. Shortnose gar showed no difference.

46. When the revetment habitat was excluded, the two reaches showed little difference in overall adjusted catches. Numbers taken along the moderate-slope bank, sandbar, and steep bank with cover were slightly higher in the entrance channel reach, while catches were slightly higher in the steep bank with no cover habitat in the upstream reach.

47. The ANOVA for hoop nets indicated that both reach and habitat affected catch rates (Table 14). Catches were higher in the navigation reach in both seasons (Tables 8 and 9). The significant habitat effect appeared to be due to the moderate-slope bank having substantially higher catches in both seasons. Although not compared statistically, hoop net catches along revetments were similar to those in other habitats in fall and lowest of all habitats in spring (Tables 8 and 9). Seine

48. A substantial difference was observed in the numbers of species of fish collected in the two reaches during the fall 1987 sampling (Table 15). of the 23 species taken overall, only 14 were captured in the entrance channel reach as compared with 21 upstream. Of the species considered to be at least moderately common, only two (channel catfish juveniles and Mississippi silvery minnow) were more common in the entrance channel reach. Silver chub, pallid shiner, blacktail shiner, and mosquitofish were more numerous in the upstream reach; in addition, several species of sunfishes, though individually uncommon, were collectively found almost exclusively upstream (ratio $=17: 1$ ).

49. Numbers per seine haul for the moderate-slope bank habitat were slightly higher in the entrance channel reach, whereas the converse was true for the sandbar habitat (Tables 8 and 9). Overall, catch rates were slightly higher in the upstream reach.

50. In the spring, 24 species were collected, approximately the same number of species as were collected in the fall. The numbers of species taken in each reach were also nearly equal (Table 16). No species unique to either reach was abundant. The four most abundant species in the study area 
exhibited substantial differences in total catches between the reaches, with river and mimic shiners being more abundant in the entrance channel reach and blacktail shiner and bullhead minnow being more common in the upstream reach. In an almost complete reversal from fall results, sunfishes (including largemouth bass and white crappie) were collectively more abundant in the entrance channel reach $(20: 4)$ than upstream. Similar to fall results, somewhat higher average catches were made in the upstream reach.

51. Because the moderate-slope bank habitat could not be sampled during the spring, catches were evaluated using two separate ANOVAs. The first analysis evaluated reach and habitat using fall data only; the second ANOVA evaluated seasons and reaches, but only for the sandbar habitat. In neither analysis were any significant effects observed (Table 17).

Condition factors

52. Condition factors were calculated for freshwater drum, blue catfish, flathead catfish, channel catfish, white bass, and smallmouth buffalo (Table 18). Values were higher in the entrance channel reach for all species except smallmouth buffalo. Only freshwater drum was abundant enough in both reaches to statistically compare condition factors, however. Condition factors of freshwater drum were significantly higher (one-tailed T-Test, $P$ $=0.003, \mathrm{df}=123$ ) in the entrance channel reach than in the upstream reach.

\section{Hydroacoustics}

53. The transects sampled in each river reach numbered from 46 to 59 each season and totaled 223 for the entire study. Echograms of the river cross section show bottom contour and detection features encountered during sampling (Figure 2). Fish detections are charted as well-defined echo traces in the water column. Submerged cover was sometimes encountered near the shoreline, particularly in the upstream reach. Acoustic noise generated by turbulence was sometimes evident where current velocities were high; this phenomenon happened rarely in September but was somewhat more common in May when water levels were higher.

54. Fish detections counted from echograms were used to calculate an index of relative fish abundance per surface area of open-water habitat. An index was used, rather than absolute density values, because transect lengths were measured as relative units from echograms rather than as actual linear 
SURFACE

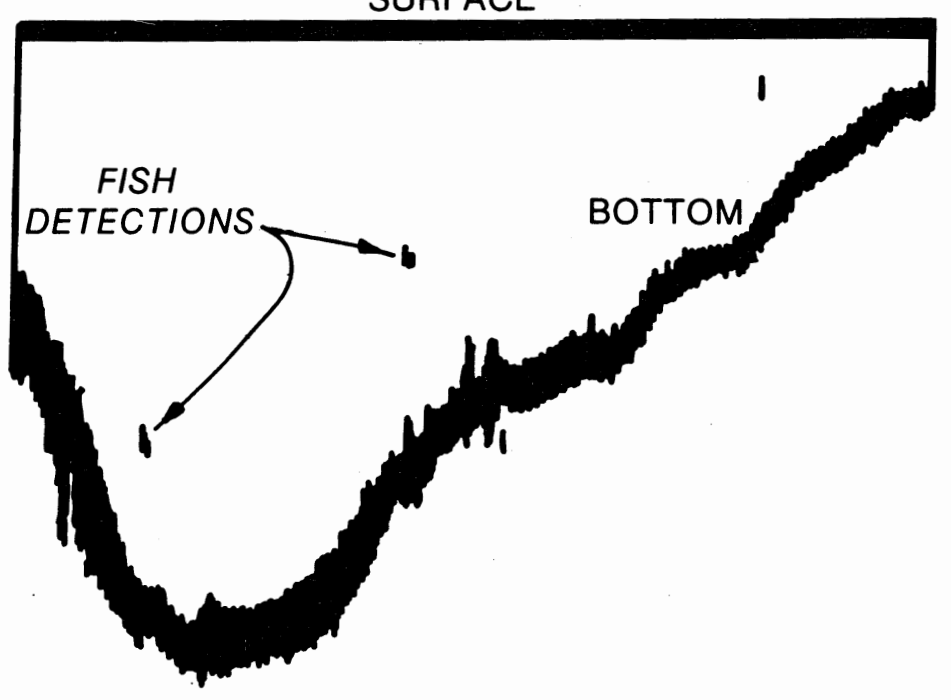

a. Fish detections

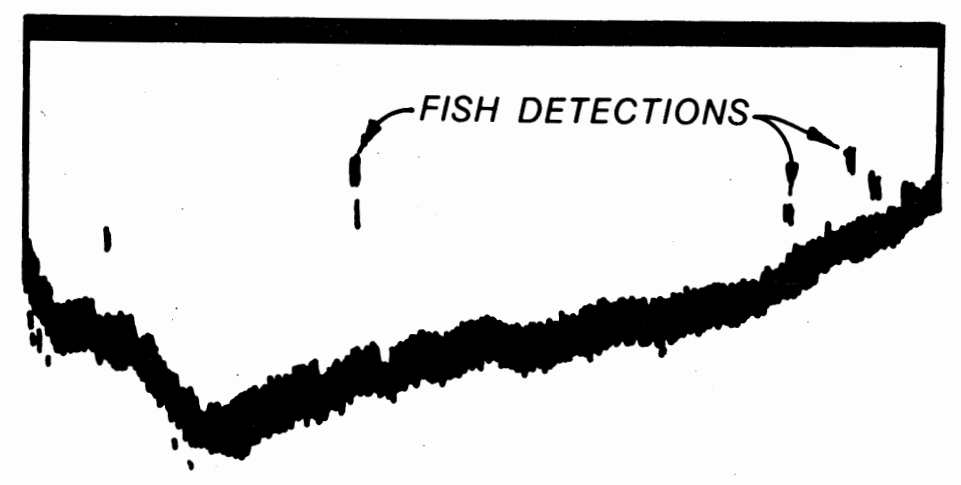

b. Fish detections

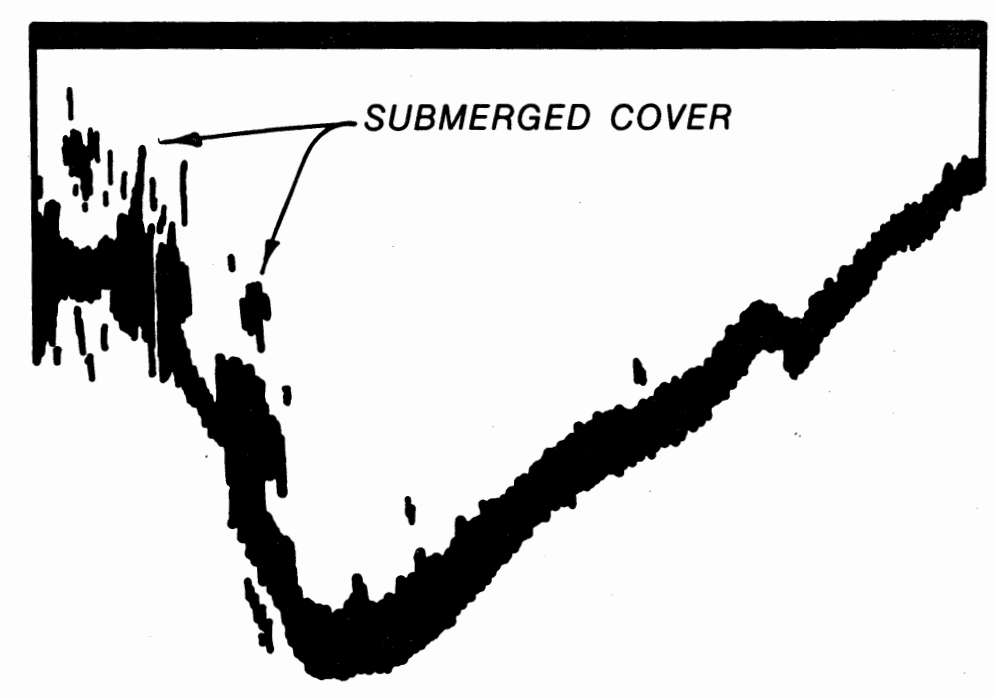

c. Submerged shoreline cover

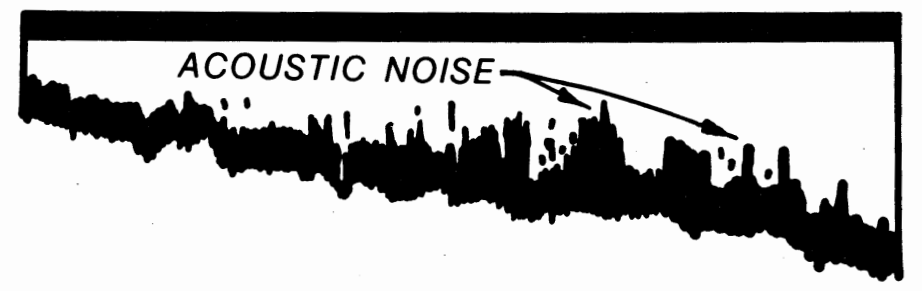

d. Acoustic noise

Figure 2. Echogram segments from hydraocoustic survey of the upstream river reach, September 1988 
distances. The computed index varied from 1.4 to 3.7 and averaged 2.5 overall. Relative densities in the two river reaches were 1.4 to 1.5 in May and 3.3 to 3.7 in September. The ANOVA confirmed the visual impression that September densities were higher than May densities and that no discernible difference existed between reaches (Table 19).

55. Acoustic size estimates were made for 231 echoes meeting the acceptance criteria for valid single fish targets (Table 20). Estimated acoustic fish sizes and tentative actual fish sizes (in parentheses) ranged from $-58.4 \mathrm{~dB}(2 \mathrm{~cm})$ to $-23.9 \mathrm{~dB}(134 \mathrm{~cm})$, with an overall mean of $-45.1 \mathrm{~dB}$ $(11 \mathrm{~cm})$. The number of accepted echoes was larger in September than May, paralleling the echogram fish counts and indicating more fish using main channel habitat during the low-water period. Mean acoustic size of fish was similar in spring and fall, but was consistently about $3 \mathrm{~dB}$ ( 4 to $5 \mathrm{~cm}$ ) larger in the upstream reach than in the entrance channel reach (Table 20). Target strength estimates of fish sampled in open water indicated that the range of sizes was similar in both seasons and reaches, but fish were on average slightly larger in the upstream reach. 


\section{Species Composition}

56. The 58 species collected in this study, plus the 5 additional ones recorded from the earlier collections, probably represent most of the species commonly found within the channel of the lower White River. As expected, this list consists of a mix of species typical of both tributaries and the mainstem Mississippi River. Because most of the adjacent land consists of bottomland hardwood forest and other wetlands (USFWS 1987) and because of the proximity of the Mississippi River, a much larger species list could undoubtedly be compiled by continued collecting. However, most additional species are likely to be rare, occurring only as waifs from more suitable nearby habitat (Table 21) or entering the White River only on spawning migrations.

57. The primary concerns pertinent to estimating possible effects of the proposed project do not involve the number of species within the study area per se, however. Rather, the questions are whether the project will cause a substantial decline in populations of any resident species and whether the project will hamper migratory species that enter from the Mississippi River and spawn upstream within the White River system.

58. Although only a single low-water and a single high-water season were sampled and only one short period was chosen to represent each, the results of the WES investigation probably reflect adequately the general state of the resident fish assemblage. The catches by the WES team included almost all species previously reported (Gulf South Research Institute 1973), plus many more. In addition, the lower White River supports heavy commercial fishing pressure, and the hoop net collections in the WES samplings corresponded well with previous catches (Mathis 1970; Arkansas Game and Fish Commission, unpublished data.) However, the WES study almost certainly did not adequately assess the presence or abundance of all migratory species (nor was it designed to) because the various species probably move into the system at different times (Table 21). 
Potential Impacts of Dam on Resident Species

59. The entrance channel reach of the study area has already undergone considerable modification as the result of large-scale dredging, revetment construction, and high levels of commercial navigation traffic. Despite this, there is no evidence to suggest that the fish populations of this reach are different from those upstream. The WES sampling indicated that similar species assemblages were present in each reach, although differences in the relative abundances of a few species were observed. Catch rates for electroshocker and hoop nets were actually higher overall in the entrance channel reach. In addition, revetments, very highly modified bank habitats found only in the the entrance channel, often contained higher numbers of fish than other habitats.

60. The high similarity of the two reaches, especially in spring, is not surprising, because they are in such close proximity. Studies on the nearby Mississippi River (Robinson 1972; Bertrand and Allen 1973; Pennington et a1. 1981; Pennington, Baker, and Bond 1983; Pennington, Baker, and Potter 1983; Baker et al. 1987) and Arkansas River (Sanders et a1., 1985) have demonstrated that few differences exist in species composition among bank habitats within the same river reach. In fact, species compositions of different, but adjacent, habitats were often more similar than widely separated segments of a single habitat type. The relative abundances of species within each habitat sometimes varied, however, with revetments often having greater numbers of many commercially important fish such as buffalos, common carp, and catfishes.

61. Condition factor values were similar to those reported by Carlander (1969, 1977) for all species tested. The generally higher condition factors of fish in the entrance channel reach, compared with those upstream, may reflect different subpopulations within some species rather than environmental differences between the two reaches. Fish from the Mississippi River may be more robust (to withstand the harsher conditions) than those resident within the White River, and they may tend to remain closer to the Mississippi.

62. River systems that have been dammed typically show large changes in their fish assemblages (Petts 1984). However, the systems that have been studied usually involved a series of dams or a single large dam that permanently changed conditions from lotic to lentic over large distances. A 
single, low dam effective only at low flows is less likely to affect resident fish populations to the same degree. Populations of typical slack-water species such as sunfishes, for example, are not likely to show increases in abundance because they will be exposed to currently prevailing riverine conditions during most of the year.

\section{Potential Impacts of Dam on Fish Migration}

63. The lower White River is one of the few remaining large tributaries to the lower Mississippi River that still contains long reaches of relatively unaltered habitat. The White River itself downstream of about RM 350, along with its many still free-flowing tributaries, provides large-river channel, sma11 river and creek, and floodplain (wetland) habitats. Thus, habitats suitable for spawning and rearing of a wide variety of fish species occur within the system.

64. Many river fish species migrate into tributaries in spring or early summer to spawn (Leggett 1977; Welcomme 1979; McKeown 1984). Some of these species spawn in shallow areas of the tributaries themselves; examples include such species as paddlefish (Purkett 1961), sturgeon (Eddy and Underhil1 1976), sauger and many redhorse suckers (Becker 1983), blue sucker (Smith 1979), and possibly also white and yellow bass (Trautman 1981). White, yellow, and perhaps also striped bass ascend other lower Mississippi River tributaries to spawn in spring (Baker 1984), although this has not yet been documented for the White River. Many other species move into wetlands associated with tributary streams (Hall 1979; Gallagher and Conner 1980). The WES's ongoing studies in the Black Swamp Wildlife Management Area of the Cache River system, for example, have demonstrated that large numbers of catfishes, buffalos, common carp, freshwater drum, and other species apparently move from the White River and/or Mississippi River into the Cache River tributary and spawn in the wetlands in large numbers in late spring.

65. Potentiai effects may not be limited to long-distance migrations. Many species (e.g. catfishes) probably also make short-distance, local movements to suitable spawning areas, to inundated floodplain areas for feeding, or among major activity areas (McKeown 1984). Several species of sturgeon, for example, regularly move between such activity areas in rivers (Hurley, Hubert, and Nickum 1987; Buckley and Kynard 1985; Wooley and Crateau 
1985). In addition, the Mississippi River may act as a refuge for lower White River fishes during summer low flows, and under heavy exploitation by commercial and sport fishermen fish stocks in the lower White River may well be maintained by recruitment from the nearby Mississippi River.

66. Information on movements of fishes in the lower Mississippi River system (including its tributary streams) is almost nil. Although a number of potentially migratory species occur in the lower White River, no studies have been done to assess the extent of migration, or even whether it actually occurs to any significant degree.

67. Migrations and local movements of fish could be affected by increased navigation traffic and its associated activities (noise, physical disturbance by boat wakes, sediment resuspension, or spills), alteration of seasonal flow patterns, and the physical presence of the dam itself. The effects of commercial navigation traffic on the physical environment are generally localized, and there have been no quantitative studies that have unequivocally shown detrimental impacts to warmwater fish as the result of barge traffic (Miller et al. 1987). Resuspension of sediment may be detrimental, since the White River is a very clear stream at most flow stages (USAED, Little Rock 1987). Again, no studies have demonstrated harmful effects of increased suspended sediment loads on fish migration. Because the anticipated structure will impound water only during the lowest flows (usually late summer and fall), flow alteration attributable to the envisioned project may be small compared with that already experienced by the river resulting from the operation of several major upstream impoundments (USFWS 1987). Even small changes in flow patterns or current velocities associated with a dam may affect fish movements, however, through effects on fish behavior. Even though a particular species may easily be able to swim against the increased current passing through dam gates, they may fail to do so for other reasons (Bell 1986). The limited available data suggest that typical river fishes such as sturgeon, paddlefish, and catfishes do move both upstream and downstream through dam gates.' At present it is not known how the observed degree of movement compares to that in unimpounded systems, although at least some restriction of movement can probably be assumed. In addition, it is also unknown whether fish move through the dam gates during high flows, low flows, or both. 
68. A second proposed project that may affect the study area reach is the Arkansas-White Cutoff (USAED, Little Rock 1987). By decreasing the amount of silt-laden Arkansas River water that enters the White River during many floods, this project may have a net beneficial effect on both resident and potential migratory fish species in the lower White River. 


\section{PART VI: CONCLUSIONS}

69. The fish populations of the White River entrance channel and the river reach immediately upstream of the Post Canal are reasonably similar. Therefore, past navigation-related activities (barge traffic, dredging, revetment construction) do not appear to have significantly reduced the quality of the aquatic habitat for resident species. Similarly, the effect of the planned low-head dam is anticipated to be minor for resident species.

70. Any restriction of the lower White River, even by a low-head dam effective only at relatively low flows, may adversely affect fish movement into or out of the system. Since the White River is one of the few remaining relatively unaltered large tributaries to the lower Mississippi River, assessment of potential damages should be made. Only general information exists pertaining to the species that may migrate into the White River or the times at which they might migrate. Conclusions drawn from the literature, and professional judgment, suggest that some species may be adversely affected, but the magnitude and significance of the effect cannot be estimated given currently available data. 


\section{REFERENCES}

Baker, J. A. 1984. "Southwest Mississippi Tributaries Study Area Environmental Inventory of Aquatic Resources," Contract Report prepared for US Army Engineer District, Vicksburg, Vicksburg, MS.

Baker, J. A., Kasul, R. L., Winfield, L. W., Bingham, C. R., Pennington, C. H., and Coleman, R. E. 1987. "An Ecological Investigation of Revetted and Natural Bank Habitats in the Lower Mississippi River," Lower Mississippi River Environmental Program Report 9, Mississippi River Commission, Vicksburg, MS.

Becker, G. 1983. Fishes of Wisconsin, University of Wisconsin Press, Madison, WI.

Beckett, D. C., and Pennington, C. H. 1986. "Water Quality, Macroinvertebrates, Larval Fishes, and Fishes of the Lower Mississippi River--a Synthesis," Technical Report E-86-12, US Army Engineer Waterways Experiment Station, Vicksburg, MS.

Bel1, M. C. 1986. "Fish Passage Development and Evaluation Program," US Army Engineer Division, North Pacific, Portland, OR.

Bertrand, B., and Allen, J. 1973. "Fish Population Survey of Aquatic Habitat Types in the Mississippi River near Cape Girardeau, Missouri," Illinois Department of Conservation, Division of Fish and Wildlife, Springfield, IL.

Buckley, J. and Kynard, B. 1985. "Yearly Movements of Shortnose Sturgeons in the Connecticut River, Transactions of the American Fisheries Society, Vo1 114, pp 813-820.

Burr, B. M., and Warren, M. L., Jr. 1986. "A Distributional Atlas of Kentucky Fishes," Scientific and Technical Series No. 4, Kentucky Nature Preserves Commission, Frankfort, KY.

Carlander, K. D. 1969. Handbook of Freshwater Fisheries Biology, Vol. I, University of Iowa Press, Ames, IA.

- 1977. Handbook of Freshwater Fisheries Biology, Vo1. II, University of Iowa Press, Ames, IA.

Cobb, S. P., and Clark, J. R. 1981. "Aquatic Habitat Studies on the Lower Mississippi River, River Mile 480-530; Report 2, Aquatic Habitat Mapping," Miscellaneous Paper E-80-1, US Army Engineer Waterways Experiment Station, Vicksburg, MS.

Eddy, S., and Underhil1, J. C. 1976. Northern Fishes, University of Minnesota Press, Minneapolis, MN.

Gallagher, R. P. and Conner, J. V. 1980. "Spatio-Temporal Distribution of Ichthyoplankton in the Lower Mississippi River, Louisiana," Proceedings of 4th Annual Larval Fish Conference, Ann Arbor, MI, pp 101-115.

Gulf South Research Institute. 1973. "Environmental Inventory of the Lower White River Basin," Final Report, Contract DACW 66-72-C-0125, for US Army Engineer District, Memphis, TN. 
Hal1, H. D. 1979. "The Spatial and Temporal Distribution of Ichthyoplankton of the Upper Atchafalaya Basin," M.Sc. Thesis, Louisiana State University, Baton Rouge, LA.

Hurley, S. T., Hubert, W. A., and Nickum, J. G. 1987. "Habitats and Movements of Shovelnose Sturgeons in the Upper Mississippi River," Transactions of the American Fisheries Society, Vol 116, pp 655-662.

Lee, D. S., Gilbert, C. R., Hocutt, C. H., Jenkins, R. E., McAllister, D. E., and Stauffer, J. R., Jr. 1980. Atlas of North American Freshwater Fishes, Publication 1980-12, North Carolina Museum of Natural History, Raleigh, NC.

Leggett, W. C. 1977. "The Ecology of Fish Migrations," Annual Review of Ecology and Systematics, Vo1 8, pp 285-308.

Love, R. H. 1971. "Dorsa1-Aspect Target Strength of an Individual Fish," Journal of the Acoustical Society of America, Vo1 49, pp 816-823.

Mathis, W. P. 1970. "The Rise and Decline of Commercial Fishing on the White River," Vol 3, Issue 1, Arkansas Game and Fish Commission, Little Rock, AR.

Mckeown, B. A. 1984. Fish Migration, Croom Helm Press, London.

Miller, A. C., Killgore, K. J., Payne, B. J. and Buckley, D. 1987. "Bibliography of Effects of Commercial Navigation Traffic in Large Waterways," Miscellaneous Paper E-87-1, US Army Engineer Waterways Experiment Station, Vicksburg, MS.

Pennington, C. H., Baker, J. A. and Potter, M. E. 1983. "Fish Populations Along Natural and Revetted Banks on the Lower Mississippi River," North American Journal of Fisheries Management, Vo1 3, pp 204-211.

Pennington, C. H., Baker, J. A. and Bond, C. L. 1983. "Fishes of Selected Aquatic Habitats on the Lower Mississippi River," Technical Report E-83-2, US Army Engineer Waterways Experiment Station, Vicksburg, MS.

Pennington, C. H., Schramm, H. L., Jr., Potter, M. E., and Farre11, M. P. 1985. "Aquatic Habitat Studies on the Lower Mississippi River, River Mile 480-530; Report 5, Fish Studies--Pilot Report," Miscellaneous Paper E-80-1, US Army Engineer Waterways Experiment Station, Vicksburg, MS •

Petts, G. F. 1984. Impounded Rivers: Perspectives for Ecological Management, John Wiley and Sons, New York.

Pflieger, W. L. 1975. "The Fishes of Missouri," Missouri Department of Conservation, Columbia, MO.

Purkett, C. A., Jr. 1961. "Reproduction and Early Development of the Paddlefish," Transactions of the American Fisheries Society, Vo1 90, No. 2, pp 125-129.

Ricker, W. E. 1975. "Computation and Interpretation of Biological Statistics of Fish Populations," Bulletin 191, Fisheries Research Board of Canada, Ottawa, Ontario, Canada.

Robins, C. R., Bailey, R. M., Bond, C. E., Brooker, J. R., Lachner, E. A., Lea, R. N., and Scott, W. B. 1980. "A List of Common and Scientific Names of Fishes from the United States and Canada," 4th ed., Special Publication No. 12, American Fisheries Society, Bethesda, MD. 
Robinson, J. W. 1972. "Population Sampling of Commercial Fish in Waters Open to Commercial Fishing," Project 4-3-R-7, Work P1an 21, Job 2, Missouri Department of Conservation, Jefferson City, MO.

Sanders, L. G., Baker, J. A., Bond, C. L., and Pennington, C. H. 1985. "Biota of Selected Aquatic Habitats of the McClellan-Kerr Arkansas River Navigation System," Technical Report E-85-6, US Army Engineer Waterways Experiment Station, Vicksburg, MS.

Smith, P. W. 1979. The Fishes of Illinois, University of Illinois Press, Urbana, IL.

Trautman, M. B. 1981. The Fishes of Ohio, Ohio State University Press, Columbus, $\mathrm{OH}$.

US Army Engineer District, Little Rock. 1987. "Arkansas-White Cutoff," Little Rock, AR.

US Fish and Wildlife Service. 1987. "Environmental Inventory and Report of the Proposed White River Entrance Channel, Arkansas and Desha Counties, Arkansas," Division of Ecological Services, Vicksburg, MS.

Wooley, C. M. and Crateau, E. J. 1985. "Movement, Microhabitat, Exploitation, and Management of Gulf of Mexico Sturgeon, Apalachicola River, Florida," North American Journal of Fisheries Management, Vo1 5, pp 590-605. 
Table 1

Physical and Chemical Conditions Observed in the Lower White

River, Arkansas, Fal1 1987 and Spring 1988

\begin{tabular}{|c|c|c|c|c|c|c|c|}
\hline Reach & $\begin{array}{c}\text { Mean, } \\
\text { (Max) } \\
\text { Thalweg } \\
\text { Depth } \\
\mathrm{ft} \\
\end{array}$ & $\begin{array}{r}\text { Current } \\
\text { Speed } \\
\mathrm{ft} / \mathrm{sec}\end{array}$ & $\begin{array}{l}\text { Water } \\
\text { Temp. } \\
{ }^{\circ} \mathrm{C} \\
\end{array}$ & $\begin{array}{l}\mathrm{DO} * \\
\mathrm{mg} / \mathrm{\ell} \\
\end{array}$ & $\underline{\mathrm{pH}}$ & $\begin{array}{l}\text { Cond. } \\
\mu \mathrm{mho} / \mathrm{cm}\end{array}$ & $\begin{array}{l}\text { Turb. } \\
\text { NTU** }\end{array}$ \\
\hline \multicolumn{8}{|c|}{ Fal1 1987} \\
\hline $\begin{array}{l}\text { Entrance } \\
\text { channel }\end{array}$ & $\begin{array}{c}20.6 \\
(35.8)\end{array}$ & $0-3$ & 23.6 & 8.7 & 7.7 & 318 & 25 \\
\hline Upstream & $\begin{array}{c}18.4 \\
(35.1)\end{array}$ & $0-3$ & 23.5 & 7.6 & 7.7 & 308 & 31 \\
\hline \multicolumn{8}{|c|}{ Spring 1988} \\
\hline $\begin{array}{l}\text { Entrance } \\
\text { channel }\end{array}$ & $\begin{array}{c}27.8 \\
(43.0)\end{array}$ & $1-6$ & 19.0 & 8.2 & 7.4 & 270 & 38 \\
\hline Upstream & $\begin{array}{c}25.6 \\
(42.3)\end{array}$ & $1-6$ & 18.9 & 8.1 & 7.4 & 277 & 40 \\
\hline
\end{tabular}

* DO = dissolved oxygen.

** NTU $=$ Nephelometer Turbidity Units. 
Table 2

Common and Scientific Names of Fish Collected

from the Lower White River, Arkansas*

\begin{tabular}{|c|c|}
\hline Common Name & Scientific Name \\
\hline $\begin{array}{l}\text { Chestnut lamprey } \\
\text { Shovelnose sturgeon } \\
\text { Bowfin } \\
\text { Spotted gar } \\
\text { Longnose gar }\end{array}$ & $\begin{array}{l}\text { Ichthyomyzon castaneus } \\
\text { Scaphirhynchus platorynchus } \\
\text { Amia calva } \\
\text { Lepisosteus oculatus } \\
\text { L. osseus }\end{array}$ \\
\hline $\begin{array}{l}\text { Shortnose gar } \\
\text { American eel } \\
\text { Goldeye } \\
\text { Mooneye } \\
\text { Skipjack herring }\end{array}$ & $\begin{array}{l}\text { L. platostomus } \\
\text { Anguizla rostrata } \\
\text { Hiodon alosoides } \\
\text { H. tergisus } \\
\text { Alosa chrysochloris }\end{array}$ \\
\hline $\begin{array}{l}\text { Gizzard shad } \\
\text { Threadfin shad } \\
\text { Blue catfish } \\
\text { Channel catfish } \\
\text { Flathead catfish }\end{array}$ & $\begin{array}{l}\text { Dorosoma cepedianum } \\
\text { D. petenense } \\
\text { Ictalurus furcatus } \\
\text { I. punctatus } \\
\text { Pylodictis olivaris }\end{array}$ \\
\hline $\begin{array}{l}\text { River carpsucker } \\
\text { Blue sucker } \\
\text { Smallmouth buffalo } \\
\text { Bigmouth buffalo } \\
\text { Black buffalo }\end{array}$ & $\begin{array}{l}\text { Carpiodes carpio } \\
\text { Cycleptus elongatus } \\
\text { Ictiobus bubalus } \\
\text { I. cyprinellus } \\
\text { I. niger }\end{array}$ \\
\hline $\begin{array}{l}\text { Shorthead redhorse } \\
\text { Common carp } \\
\text { Cypress minnow } \\
\text { Mississippi silvery minnow } \\
\text { Speckled chub }\end{array}$ & $\begin{array}{l}\text { Moxostoma macrolepidotum } \\
\text { Cyprinus carpio } \\
\text { Hybognathus hayi } \\
\text { H. nuchalis } \\
\text { Hybopsis aestivalis }\end{array}$ \\
\hline $\begin{array}{l}\text { Bigeye chub } \\
\text { Silver chub } \\
\text { Pallid shiner } \\
\text { Emerald shiner } \\
\text { River shiner }\end{array}$ & $\begin{array}{l}\text { H. amblops } \\
\text { H. storeriana } \\
\text { Notropis amnis } \\
\text { N. atherinoides } \\
\text { N. blennius }\end{array}$ \\
\hline $\begin{array}{l}\text { Pugnose minnow } \\
\text { Ribbon shiner } \\
\text { Silverband shiner } \\
\text { Weed shiner } \\
\text { Blacktail shiner }\end{array}$ & $\begin{array}{l}N . \text { emiliae } \\
N . \text { fumeus } \\
N . \text { shumardi } \\
N . \text { texanus } \\
N . \text { venustus }\end{array}$ \\
\hline
\end{tabular}

* Robins et al. (1980). 
Table 2 (Concluded)

\begin{tabular}{|c|c|}
\hline Common Name & Scientific Name \\
\hline $\begin{array}{l}\text { Mimic shiner } \\
\text { Bullhead minnow } \\
\text { Mosquitofish } \\
\text { Golden topminnow } \\
\text { Brook silverside }\end{array}$ & $\begin{array}{l}\text { N. volucellus } \\
\text { Pimephales vigilax } \\
\text { Gambusia affinis } \\
\text { Fundulus chrysotus } \\
\text { Labidesthes sicculus }\end{array}$ \\
\hline $\begin{array}{l}\text { Inland silverside } \\
\text { Green sunfish } \\
\text { Warmouth } \\
\text { Orangespotted sunfish } \\
\text { Bluegill }\end{array}$ & $\begin{array}{l}\text { Menidia beryllina } \\
\text { Lepomis cyanellus } \\
\text { L. gulosus } \\
\text { L. humilis } \\
\text { L. macrochirus }\end{array}$ \\
\hline $\begin{array}{l}\text { Longear sunfish } \\
\text { Redear sunfish } \\
\text { Spotted bass } \\
\text { Largemouth bass } \\
\text { White crappie }\end{array}$ & $\begin{array}{l}\text { L. megalotis } \\
\text { L. microlophus } \\
\text { Microptems punctulatus } \\
\text { M. salmoides } \\
\text { Pomoxis annularis }\end{array}$ \\
\hline $\begin{array}{l}\text { Black crappie } \\
\text { White bass } \\
\text { Yellow bass } \\
\text { Striped bass } \\
\text { Scaly sand darter }\end{array}$ & $\begin{array}{l}\text { P. nigromaculatus } \\
\text { Morone chrysops } \\
\text { M. mississippiensis } \\
\text { M. saxatilis } \\
\text { Ammocrypta vivax }\end{array}$ \\
\hline $\begin{array}{l}\text { Bluntnose darter } \\
\text { Sauger } \\
\text { Freshwater drum }\end{array}$ & $\begin{array}{l}\text { Etheostoma chlorosomum } \\
\text { Stizostedion canadense } \\
\text { Aplodinotus grunniens }\end{array}$ \\
\hline
\end{tabular}


Table 3

Fish Collected by Boat Electroshocker from the Entrance Channe1*

Reach of the Lower White River, Arkansas, Fall 1987

\begin{tabular}{|c|c|c|c|c|c|c|}
\hline Species** & $\begin{array}{l}\text { Mod.- } \\
\text { Slope } \\
\text { Bank } \\
\end{array}$ & $\begin{array}{l}\text { Sand- } \\
\text { bar }\end{array}$ & $\begin{array}{l}\text { Steep } \\
\text { Bank, } \\
\text { Cover } \\
\end{array}$ & $\begin{array}{c}\text { Steep } \\
\text { Bank, } \\
\text { No Cover } \\
\end{array}$ & $\begin{array}{l}\text { Revet- } \\
\text { ment }\end{array}$ & Total \\
\hline Bowfin & & 1 & 2 & & 1 & 4 \\
\hline Longnose gar & 3 & 1 & 3 & & & 7 \\
\hline Shortnose gar & & 2 & 3 & & & 5 \\
\hline Goldeye & 1 & & 1 & & & 2 \\
\hline Skipjack herring & 1 & & 4 & 1 & 2 & 8 \\
\hline Gizzard shad & 25 & 159 & 4 & 6 & 28 & 222 \\
\hline Threadfin shad & 7 & 3 & & & 8 & 18 \\
\hline Blue catfish & 8 & & & & & 8 \\
\hline Channel catfish & & & & 1 & 2 & 3 \\
\hline Flathead catfish & 1 & & 1 & & & 2 \\
\hline Smallmouth buffalo & & & 1 & & & 1 \\
\hline Bigmouth buffalo & & & 4 & & & 4 \\
\hline Common carp & 1 & & 5 & 3 & 1 & 10 \\
\hline Miss. silvery minnow & & 1 & & & & 1 \\
\hline Emerald shiner & 12 & 2 & 1 & 2 & 5 & 22 \\
\hline River shiner & & 3 & & & 1 & 4 \\
\hline Blacktail shiner & & & 1 & & 11 & 12 \\
\hline Bullhead minnow & & & 3 & & 4 & 7 \\
\hline Bluegill & & & 8 & 1 & 7 & 16 \\
\hline Longear sunfish & & & & & 1 & 1 \\
\hline Spotted bass & & & & & 2 & 2 \\
\hline Largemouth bass & & & & 1 & 1 & 2 \\
\hline White bass & 1 & 1 & 2 & 2 & & 6 \\
\hline White crappie & 1 & & 2 & & 2 & 5 \\
\hline Black crappie & & & 4 & & & 4 \\
\hline Freshwater drum & & 1 & 1 & & 6 & 8 \\
\hline Total species & 11 & 10 & 19 & 8 & 5 & 26 \\
\hline $\begin{array}{l}\text { Total number } \\
\text { (without revetment) }\end{array}$ & 61 & 174 & 51 & 17 & 81 & $\begin{array}{c}384 \\
(303)\end{array}$ \\
\hline
\end{tabular}

* Descriptions of reaches and bank types (= habitats) explained in text. ** Common and scientific names listed in Table 2. 
Table 4

Fish Collected by Boat Electroshocker from the Upstream*

Reach of the Lower White River, Arkansas, Fall 1987

\begin{tabular}{|c|c|c|c|c|c|}
\hline Species** & $\begin{array}{l}\text { Mod.- } \\
\text { Slope } \\
\text { Bank } \\
\end{array}$ & $\begin{array}{c}\text { Sand- } \\
\text { bar }\end{array}$ & $\begin{array}{l}\text { Steep } \\
\text { Bank, } \\
\text { Cover } \\
\end{array}$ & $\begin{array}{c}\text { Steep } \\
\text { Bank, } \\
\text { No Cover } \\
\end{array}$ & Total \\
\hline Bowfin & & & 1 & & 1 \\
\hline Longnose gar & 2 & 4 & 7 & & 13 \\
\hline Shortnose gar & 3 & 11 & 12 & 2 & 28 \\
\hline American eel & & & 1 & & 1 \\
\hline Mooneye & & & & 1 & 1 \\
\hline Skipjack herring & & & & 3 & 3 \\
\hline Gizzard shad & 56 & 82 & 17 & 19 & 174 \\
\hline Channel catfish & 1 & & & 2 & 3 \\
\hline Flathead catfish & 1 & & 1 & 1 & 3 \\
\hline River carpsucker & & 3 & & & 3 \\
\hline Blue sucker & & & 1 & & 1 \\
\hline Smallmouth buffalo & & & 1 & & 1 \\
\hline Common carp & 2 & 1 & 3 & 1 & 7 \\
\hline Miss. silvery minnow & 1 & 28 & & 1 & 30 \\
\hline Silver chub & 4 & 3 & & & 7 \\
\hline Emerald shiner & 10 & 23 & 57 & 32 & 122 \\
\hline Blacktail shiner & 5 & 2 & 41 & 3 & 51 \\
\hline Bullhead minnow & 1 & 1 & & & 2 \\
\hline Green sunfish & & & & 1 & 1 \\
\hline Bluegill & & & 2 & & 2 \\
\hline Redear sunfish & & 1 & & & 1 \\
\hline Largemouth bass & & & 1 & & 1 \\
\hline White bass & & 1 & 1 & 1 & 3 \\
\hline White crappie & & & 1 & & 1 \\
\hline Sauger & 1 & & & & 1 \\
\hline Freshwater drum & 7 & & 1 & 11 & 19 \\
\hline Total species & 13 & 12 & 16 & 13 & 26 \\
\hline Total number & 94 & 160 & 148 & 78 & 480 \\
\hline
\end{tabular}

* Descriptions of reaches and bank types (= habitats) explained in text.

** Common and scientific names listed in Table 2. 
Table 5

Fish Collected by Boat Electroshocker from the Entrance Channe1* Reach of the Lower White River, Arkansas, Spring 1988

\begin{tabular}{|c|c|c|c|c|c|c|}
\hline Species** & $\begin{array}{l}\text { Mod.- } \\
\text { S1ope } \\
\text { Bank } \\
\end{array}$ & $\begin{array}{c}\text { Sand- } \\
\text { bar }\end{array}$ & $\begin{array}{l}\text { Steep } \\
\text { Bank, } \\
\text { cover } \\
\end{array}$ & $\begin{array}{c}\text { Steep } \\
\text { Bank, } \\
\text { No Cover } \\
\end{array}$ & $\begin{array}{l}\text { Revet- } \\
\text { ment }\end{array}$ & Totalt \\
\hline Chestnut lamprey & $1(1)$ & $1(1)$ & & & 1 & $3(3)$ \\
\hline Bowfin & $1(1)$ & & 1 & & 1 & $3(3)$ \\
\hline Spotted gar & & & & & 1 & $1(1)$ \\
\hline Longnose gar & $2(3)$ & & 5 & $1(1)$ & 2 & $10(11)$ \\
\hline Shortnose gar & $5(6)$ & $5(7)$ & & & 4 & $13(17)$ \\
\hline Goldeye & & & 2 & & & $2(2)$ \\
\hline Gizzard shad & $49(73)$ & $33(49)$ & 59 & $207(310)$ & 75 & $433(566)$ \\
\hline Threadfin shad & $55(82)$ & $92(138)$ & 204 & $35(52)$ & 254 & $640(730)$ \\
\hline B1ue catfish & & & 2 & & 2 & $4(4)$ \\
\hline Channel catfish & $3(5)$ & $2(3)$ & & $1(1)^{\prime}$ & 1 & $7(10)$ \\
\hline Flathead catfish & & & 1 & $1(1)$ & 2 & $4(4)$ \\
\hline River carpsucker & $7(10)$ & $1(1)$ & & & 6 & $14(17)$ \\
\hline Smallmouth buffalo & & $1(1)$ & 2 & & 1 & $4(4)$ \\
\hline Bigmouth buffalo & & & 1 & & & $1(1)$ \\
\hline Common carp & $20(30)$ & $3(5)$ & 10 & & 7 & $40(52)$ \\
\hline Miss. silvery minnow & $10(15)$ & $1(1)$ & 1 & & 3 & $15(20)$ \\
\hline Emerald shiner & $3(5)$ & & & $4(6)$ & & $7(11)$ \\
\hline River shiner & & & & $2(3)$ & 1 & $3(4)$ \\
\hline Blacktail shiner & $11(16)$ & & 5 & $57(88)$ & 13 & $86(122)$ \\
\hline Bullhead minnow & $4(6)$ & & & $9(13)$ & 1 & $14(20)$ \\
\hline Brook silverside & & $1(1)$ & & & & $1(1)$ \\
\hline Inland silverside & $1(1)$ & & & & & $1(1)$ \\
\hline Orangespotted sunfish & & & & $1(1)$ & 2 & $3(3)$ \\
\hline Bluegill & $6(9)$ & & & $8(12)$ & 2 & $16(23)$ \\
\hline Longear sunfish & & & & $2(3)$ & 1 & $3(4)$ \\
\hline Redear sunfish & $1(1)$ & & & $1(1)$ & & $2(2)$ \\
\hline White bass & $1(1)$ & $3(5)$ & & $1(1)$ & & $5(7)$ \\
\hline Striped bass & & $1(1)$ & & & & $1(1)$ \\
\hline White crappie & & & 1 & & & $1(1)$ \\
\hline Black crappie & $1(1)$ & & & & & $1(1)$ \\
\hline Freshwater drum & $26(40)$ & $49(73)$ & 2 & $7(10)$ & 32 & $116(157)$ \\
\hline Total species & 19 & 13 & 14 & 15 & 22 & 31 \\
\hline $\begin{array}{l}\text { Total numbers } \\
\text { (without } \\
\text { revetment) }\end{array}$ & $206(306)$ & $193(286)$ & 296 & $337(503)$ & 414 & $\begin{array}{l}1446(1805) \\
(1032)(1391)\end{array}$ \\
\hline
\end{tabular}

\footnotetext{
* Description of reaches and bank types (= habitats) explained in text.

** Common and scientific names listed in Table 2.

$\dagger$ Catches presented as actual and (adjusted) numbers. Adjusted catches are scaled to a standard of 25 min of electroshocking.
} 
Table 6

Fish Collected by Boat Electroshocker from the Upstream*

Reach of the Lower White River, Arkansas, Spring 1988

\begin{tabular}{|c|c|c|c|c|c|}
\hline Species** & $\begin{array}{l}\text { Mod.- } \\
\text { Slope } \\
\text { Bank } \\
\end{array}$ & $\begin{array}{c}\text { Sand- } \\
\text { bar }\end{array}$ & $\begin{array}{l}\text { Steep } \\
\text { Bank, } \\
\text { Cover } \\
\end{array}$ & $\begin{array}{c}\text { Steep } \\
\text { Bank, } \\
\text { No Cover } \\
\end{array}$ & Totalt \\
\hline Longnose gar & 1 & & $4(3)$ & 2 & $7(6)$ \\
\hline Shortnose gar & 7 & & $2(2)$ & & $9(9)$ \\
\hline American eel & & & $1(1)$ & & $1(1)$ \\
\hline Goldeye & & 1 & & 1 & $2(2)$ \\
\hline Skipjack herring & 1 & & & & $1(1)$ \\
\hline Gizzard shad & 121 & 47 & $50(42)$ & 102 & $320(312)$ \\
\hline Threadfin shad & 20 & 24 & $21(18)$ & 43 & $108(105)$ \\
\hline Blue catfish & 2 & & $2(2)$ & & $4(4)$ \\
\hline Channel catfish & 1 & 2 & & & $3(3)$ \\
\hline Flathead catfish & & 1 & & & $1(1)$ \\
\hline River carpsucker & 11 & 7 & $1(1)$ & & $19(19)$ \\
\hline Smallmouth buffalo & 4 & & $7(6)$ & & $11(10)$ \\
\hline Bigmouth buffalo & & & $1(1)$ & & $1(1)$ \\
\hline Black buffalo & 1 & & $1(1)$ & & $2(2)$ \\
\hline Shorthead redhorse & & 1 & & & $1(1)$ \\
\hline Common carp & 4 & 1 & $2(2)$ & & $7(7)$ \\
\hline Miss. silvery minnow & 1 & 9 & & 2 & $12(12)$ \\
\hline Emerald shiner & & 3 & $1(1)$ & 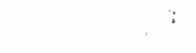 & $4(4)$ \\
\hline Ribbon shiner & & 1 & & & $1(1)$ \\
\hline Blacktail shiner & 10 & 78 & & 3 & $91(91)$ \\
\hline Bullhead minnow & 2 & 11 & & & $13(13)$ \\
\hline Brook silverside & & 2 & & & $2(2)$ \\
\hline Inland silverside & 1 & 1 & $1(1)$ & & $3(3)$ \\
\hline Orangespotted sunfish & 1 & & & & $1(1)$ \\
\hline Bluegill & 1 & & $7(6)$ & & $8(7)$ \\
\hline Longear sunfish & 1 & 3 & & & $4(4)$ \\
\hline Redear sunfish & 1 & 1 & & & $2(2)$ \\
\hline Largemouth bass & 1 & & & 1 & $2(2)$ \\
\hline White bass & 2 & & & & $2(2)$ \\
\hline Yellow bass & & 1 & $1(1)$ & & $2(2)$ \\
\hline White crappie & & & $1(1)$ & & $1(1)$ \\
\hline Freshwater drum & 4 & 31 & $2(2)$ & 12 & $49(49)$ \\
\hline Total species & 22 & 19 & 17 & 8 & 32 \\
\hline Total numbers & 198 & 225 & $105(91)$ & 166 & $694(680)$ \\
\hline
\end{tabular}

* Description of reaches and bank types (= habitats) explained in text. ** Common and scientific names listed in Table 2.

$\dagger$ Catches presented as actual and (adjusted) numbers. Adjusted catches are scaled to a standard of $25 \mathrm{~min}$ of electroshocking. 
Table 7

Analysis of Variance* Results for Electroshocking Catches,

Lower White River Study

\begin{tabular}{|c|c|c|c|c|c|}
\hline $\begin{array}{c}\text { Source } \\
\text { of } \\
\text { Variation }\end{array}$ & $\begin{array}{c}\text { Sum } \\
\text { of } \\
\text { Squares } \\
\end{array}$ & $\begin{array}{l}\text { Degrees } \\
\text { of } \\
\text { Freedom } \\
\end{array}$ & $\begin{array}{l}\text { Mean } \\
\text { Square }\end{array}$ & F-Ratio & $\begin{array}{l}\text { Signi- } \\
\text { ficance } \\
\text { Leve1 } \\
\end{array}$ \\
\hline Season & 0.9020 & 1 & 0.9020 & 33.28 & $<0.0005$ \\
\hline Reach & 0.0043 & 1 & 0.0043 & $<1$ & N.S.** \\
\hline Habitat & 0.2889 & 3 & 0.0963 & 3.55 & $<0.05$ \\
\hline Season $\mathrm{X}$ reach & 0.4091 & 1 & 0.4091 & 15.10 & $<0.01$ \\
\hline Season $\mathrm{X}$ habitat & 0.3728 & 3 & 0.1243 & 4.59 & $<0.025$ \\
\hline Reach X habitat & 0.0065 & 3 & 0.0022 & $<1$ & N.S. \\
\hline $\begin{array}{l}\text { Season } X \text { reach } X \\
\text { habitat }\end{array}$ & 0.1638 & 3 & 0.0546 & 2.01 & N.S \\
\hline Error & 0.4336 & 16 & 0.0271 & & \\
\hline Total & 2.5810 & 31 & & & \\
\hline
\end{tabular}

* Three-way factorial, fixed effects ANOVA, $n=2$ observations per cell; data are catches per minute of electroshocking transformed as $\log 10$ $(y+1)$.

** N.S. $=$ not significant. 
Table 8

Catch Statistics for Three Fish-Collecting Gears for the

Entrance Channel Reach, Lower White River, Arkansas*

\begin{tabular}{|c|c|c|c|c|c|c|}
\hline Gear & $\begin{array}{l}\text { Mod.- } \\
\text { Slope } \\
\text { Bank }\end{array}$ & $\begin{array}{c}\text { Sand- } \\
\text { bar }\end{array}$ & $\begin{array}{l}\text { Steep } \\
\text { Bank, } \\
\text { Cover } \\
\end{array}$ & $\begin{array}{l}\text { Steep } \\
\text { Bank, } \\
\text { No Cover } \\
\end{array}$ & $\begin{array}{c}\text { Revet- } \\
\text { ment } \\
\end{array}$ & Mean** \\
\hline & & Fall & 987 & & & \\
\hline \multicolumn{7}{|l|}{ Electoshocker } \\
\hline $\begin{array}{l}\text { Mean } \\
\text { S.D. } \\
\text { N (minutes) }\end{array}$ & $\begin{array}{l}2.44 \\
(1.53) \\
25.05\end{array}$ & $\begin{array}{l}7.00 \\
(1.63) \\
25.02\end{array}$ & $\begin{array}{l}2.42 \\
(0.14) \\
25.20\end{array}$ & $\begin{array}{l}0.71 \\
(0.32) \\
24.42\end{array}$ & $\begin{array}{l}3.24 \\
(0.18) \\
25.02\end{array}$ & $\begin{array}{c}3.16 \\
(2.33) \\
124.71\end{array}$ \\
\hline \multicolumn{7}{|l|}{ Hoop net } \\
\hline $\begin{array}{l}\text { Mean } \\
\text { S.D. } \\
N \text { (net-days) }\end{array}$ & $\begin{array}{l}2.65 \\
(1.57) \\
20\end{array}$ & $\begin{array}{l}1.35 \\
(1.09) \\
20\end{array}$ & $\begin{array}{l}1.17 \\
(1.38) \\
18\end{array}$ & $\begin{array}{l}1.68 \\
(1.11) \\
19\end{array}$ & $\begin{array}{l}1.85 \\
(1.23) \\
20\end{array}$ & $\begin{array}{l}1.75 \\
(0.85) \\
97\end{array}$ \\
\hline \multicolumn{7}{|l|}{ Seine } \\
\hline $\begin{array}{l}\text { Mean } \\
\text { S.D. } \\
\text { N (50-ft hauls) }\end{array}$ & $\begin{array}{c}64.16 \\
(69.87) \\
6\end{array}$ & $\begin{array}{c}51.00 \\
(41.11) \\
6\end{array}$ & & & & $\begin{array}{l}57.58 \\
(55.08) \\
12\end{array}$ \\
\hline \multicolumn{7}{|c|}{ Spring 1988} \\
\hline \multicolumn{7}{|l|}{ Electroshocker } \\
\hline $\begin{array}{l}\text { Mean } \\
\text { S.D. } \\
\text { N (minutes) }\end{array}$ & $\begin{array}{l}12.36 \\
(1.02) \\
16.70\end{array}$ & $\begin{array}{l}11.55 \\
(3.35) \\
16.70\end{array}$ & $\begin{array}{l}9.63 \\
(9.38) \\
25.00\end{array}$ & $\begin{array}{c}20.22 \\
(12.30) \\
16.70\end{array}$ & $\begin{array}{l}17.83 \\
(4.59) \\
25.00\end{array}$ & $\begin{array}{c}14.32 \\
(6.94) \\
100.10\end{array}$ \\
\hline \multicolumn{7}{|l|}{ Hoop net } \\
\hline $\begin{array}{l}\text { Mean } \\
\text { S.D. } \\
\text { N (net-days) }\end{array}$ & $\begin{array}{l}1.94 \\
(1.69) \\
16\end{array}$ & $\begin{array}{l}1.47 \\
(0.96) \\
19\end{array}$ & $\begin{array}{l}1.23 \\
(2.09) \\
13\end{array}$ & $\begin{array}{l}1.08 \\
(0.86) \\
13\end{array}$ & $\begin{array}{l}1.06 \\
(0.93) \\
16\end{array}$ & $\begin{array}{l}1.39 \\
(1.00) \\
77\end{array}$ \\
\hline \multicolumn{7}{|l|}{ Seine } \\
\hline $\begin{array}{l}\text { Mean } \\
\text { S.D. } \\
\text { N (50-ft hauls) }\end{array}$ & & $\begin{array}{l}89.00 \\
(52.82) \\
6\end{array}$ & & & & $\begin{array}{c}89.00 \\
(52.82) \\
6\end{array}$ \\
\hline
\end{tabular}

* Description of reaches and bank types (= habitats) explained in text.

** Mean and standard deviation (S.D.) for electroshocker based on $n=2$ shocking runs per habitat, each expressed as total fish collected per minute; total electroshocking time shown. Mean and S.D. for hoop net and seine based on numbers of net-days and 50-ft hauls, as presented. 
Table 9

Catch Statistics for Three Fish-Collecting Gears for the

Upstream Reach, Lower White River, Arkansas*

\begin{tabular}{|c|c|c|c|c|c|}
\hline Gear & $\begin{array}{l}\text { Mod.- } \\
\text { Slope } \\
\text { Bank } \\
\end{array}$ & $\begin{array}{c}\text { Sand- } \\
\text { bar }\end{array}$ & $\begin{array}{l}\text { Steep } \\
\text { Bank, } \\
\text { Cover }\end{array}$ & $\begin{array}{c}\text { Steep } \\
\text { Bank, } \\
\text { No Cover } \\
\end{array}$ & Mean** \\
\hline & & Fal1 1987 & & & \\
\hline \multicolumn{6}{|l|}{ Electoshocker } \\
\hline $\begin{array}{l}\text { Mean } \\
\text { S.D. } \\
\mathrm{N} \text { (minutes) }\end{array}$ & $\begin{array}{l}3.74 \\
(0.04) \\
25.15\end{array}$ & $\begin{array}{l}6.42 \\
(0.82) \\
24.90\end{array}$ & $\begin{array}{l}5.96 \\
(0.49) \\
25.02\end{array}$ & $\begin{array}{l}3.13 \\
(1.59) \\
25.00\end{array}$ & $\begin{array}{c}4.81 \\
(1.66) \\
100.07\end{array}$ \\
\hline \multicolumn{6}{|l|}{ Hoop net } \\
\hline $\begin{array}{l}\text { Mean } \\
\text { S.D. } \\
\text { N (net-days) }\end{array}$ & $\begin{array}{l}1.13 \\
(1.12) \\
24\end{array}$ & $\begin{array}{l}0.92 \\
(1.06) \\
24\end{array}$ & $\begin{array}{l}0.46 \\
(0.59) \\
24\end{array}$ & $\begin{array}{l}1.00 \\
(1.22) \\
24\end{array}$ & $\begin{array}{l}0.88 \\
(0.73) \\
96\end{array}$ \\
\hline \multicolumn{6}{|l|}{ Seine } \\
\hline $\begin{array}{l}\text { Mean } \\
\text { S.D. } \\
N \text { (50-ft hauls) }\end{array}$ & $\begin{array}{c}55.33 \\
(29.75) \\
6\end{array}$ & $\begin{array}{c}88.83 \\
(63.09) \\
6\end{array}$ & & & $\begin{array}{l}72.08 \\
(50.18) \\
12\end{array}$ \\
\hline & & Spring 1988 & & & \\
\hline \multicolumn{6}{|l|}{ Electroshocker } \\
\hline $\begin{array}{l}\text { Mean } \\
\text { S.D. } \\
\mathrm{N} \text { (minutes) }\end{array}$ & $\begin{array}{l}7.32 \\
(1.88) \\
25.80\end{array}$ & $\begin{array}{l}9.70 \\
(3.02) \\
25.00\end{array}$ & $\begin{array}{l}3.59 \\
(0.77) \\
30.00\end{array}$ & $\begin{array}{l}6.03 \\
(2.59) \\
25.00\end{array}$ & $\begin{array}{c}6.66 \\
(2.90) \\
105.80\end{array}$ \\
\hline \multicolumn{6}{|l|}{ Hoop net } \\
\hline $\begin{array}{l}\text { Mean } \\
\text { S.D. } \\
\text { N (net-days) }\end{array}$ & $\begin{array}{l}1.33 \\
(1.97) \\
24\end{array}$ & $\begin{array}{l}0.79 \\
(0.78) \\
24\end{array}$ & $\begin{array}{l}1.39 \\
(1.59) \\
23\end{array}$ & $\begin{array}{l}1.44 \\
(1.85) \\
18\end{array}$ & $\begin{array}{l}1.22 \\
(1.34) \\
79\end{array}$ \\
\hline \multicolumn{6}{|l|}{ Seine } \\
\hline $\begin{array}{l}\text { Mean } \\
\text { S.D. } \\
N(50-\mathrm{ft} \text { hauls })\end{array}$ & & $\begin{array}{c}101.33 \\
(66.35) \\
6\end{array}$ & & & $\begin{array}{l}101.33 \\
(66.35)\end{array}$ \\
\hline
\end{tabular}

* Description of reaches and bank types (= habitats) explained in text.

** Mean and standard deviation (S.D.) for electroshocker based on $n=2$ shocking runs per habitat, each expressed as total fish collected per minute; total electroshocking time shown. Mean and S.D. for hoop net and seine based on numbers of net-days and 50-ft hauls, as presented. 
Table 10

Fish Collected by Hoop Nets from the Entrance Channel*

Reach of the Lower White River, Arkansas, Fall 1987

\begin{tabular}{|c|c|c|c|c|c|c|}
\hline Species** & $\begin{array}{l}\text { Mod.- } \\
\text { Slope } \\
\text { Bank } \\
\end{array}$ & $\begin{array}{l}\text { Sand- } \\
\text { bar }\end{array}$ & $\begin{array}{l}\text { Steep } \\
\text { Bank, } \\
\text { Cover } \\
\end{array}$ & $\begin{array}{c}\text { Steep } \\
\text { Bank, } \\
\text { No Cover } \\
\end{array}$ & $\begin{array}{l}\text { Revet- } \\
\text { ment }\end{array}$ & Total† \\
\hline Shortnose gar & $3(4)$ & $2(2)$ & & & $2(2)$ & $7(8)$ \\
\hline American ee1 & $1(1)$ & & & $1(1)$ & $6(7)$ & $8(9)$ \\
\hline Gizzard shad & $1(1)$ & & & & & $1(1)$ \\
\hline Blue catfish & $5(6)$ & $6(7)$ & $3(4)$ & $4(5)$ & $7(8)$ & $25(30)$ \\
\hline Channel catfish & $2(2)$ & $1(1)$ & $1(1)$ & $2(3)$ & & $6(7)$ \\
\hline Flathead catfish & $5(6)$ & $5(6)$ & $2(3)$ & $7(9)$ & $7(8)$ & $26(32)$ \\
\hline River carpsucker & & & & $2(3)$ & $1(1)$ & $3(4)$ \\
\hline Smallmouth buffalo & $3(4)$ & & $1(1)$ & $3(4)$ & $2(2)$ & $9(11)$ \\
\hline Bigmouth buffalo & $3(4)$ & & & & & $3(4)$ \\
\hline Bluegill & & & & & $1(1)$ & $1(1)$ \\
\hline White bass & & $1(1)$ & & $1(1)$ & & $2(2)$ \\
\hline White crappie & $5(6)$ & $1(1)$ & $3(4)$ & $1(1)$ & $1(1)$ & $11(13)$ \\
\hline Freshwater drum & $25(30)$ & $11(13)$ & $4(5)$ & $17(21)$ & $10(12)$ & $67(81)$ \\
\hline Total species & 10 & 7 & 6 & 9 & 9 & 13 \\
\hline $\begin{array}{l}\text { Total numbers } \\
\text { (without revetment) }\end{array}$ & $53(64)$ & $27(31)$ & $14(18)$ & $38(48)$ & $37(42)$ & $\begin{array}{c}169(203) \\
{[132(161)]}\end{array}$ \\
\hline
\end{tabular}

* Description of reaches and bank types (= habitats) explained in text. ** Common and scientific names listed in Table 2.

$\dagger$ Catches presented as actual and (adjusted) numbers. Adjusted catches are scaled to a standard of 24 net-days. 
Table 11

Fish Collected by Hoop Nets from the Upstream* Reach of

the Lower White River, Arkansas, Fall 1987

\begin{tabular}{|c|c|c|c|c|c|}
\hline Species** & $\begin{array}{l}\text { Mod.- } \\
\text { Slope } \\
\text { Bank } \\
\end{array}$ & $\begin{array}{c}\text { Sand- } \\
\text { bar }\end{array}$ & $\begin{array}{l}\text { Steep } \\
\text { Bank, } \\
\text { Cover } \\
\end{array}$ & $\begin{array}{c}\text { Steep } \\
\text { Bank, } \\
\text { No Cover } \\
\end{array}$ & Total \\
\hline Longnose gar & 3 & 3 & 3 & & 9 \\
\hline Shortnose gar & 2 & 2 & 1 & 1 & 6 \\
\hline American eel & 1 & & 1 & & 2 \\
\hline Gizzard shad & & 1 & & & 1 \\
\hline Blue catfish & 3 & & & 1 & 4 \\
\hline Channel catfish & 6 & 2 & & 3 & 11 \\
\hline Flathead catfish & 1 & & 2 & & 3 \\
\hline Smallmouth buffalo & & 2 & & 2 & 4 \\
\hline Bigmouth buffalo & & 2 & & & 2 \\
\hline Common carp & & & & 1 & 1 \\
\hline Bluegill & 2 & 2 & & & 4 \\
\hline White bass & & 1 & & 1 & 2 \\
\hline White crappie & & 1 & & & 1 \\
\hline Black crappie & & & 1 & 1 & 2 \\
\hline Freshwater drum & 11 & 6 & 3 & 14 & 34 \\
\hline Total species & 8 & 10 & 6 & 8 & 15 \\
\hline Total numbers & 29 & 22 & 11 & 24 & 86 \\
\hline
\end{tabular}

* Description of reaches and bank types (= habitats) explained in text. ** Common and scientific names listed in Table 2. 
Table 12

Fish Collected by Hoop Nets from the Entrance Channe1* Reach of the Lower White River, Arkansas, Spring 1988

\begin{tabular}{|c|c|c|c|c|c|c|}
\hline Species** & $\begin{array}{c}\text { Mod.- } \\
\text { Slope } \\
\text { Bank } \\
\end{array}$ & $\begin{array}{l}\text { Sand- } \\
\text { bar }\end{array}$ & $\begin{array}{l}\text { Steep } \\
\text { Bank, } \\
\text { Cover }\end{array}$ & $\begin{array}{c}\text { Steep } \\
\text { Bank, } \\
\text { No Cover } \\
\end{array}$ & $\begin{array}{l}\text { Revet- } \\
\text { ment }\end{array}$ & Total† \\
\hline Longnose gar & $1(2)$ & $2(3)$ & & $1(2)$ & $1(2)$ & $5(9)$ \\
\hline Shortnose gar & $4(6)$ & $1(1)$ & $1(2)$ & $2(4)$ & $1(2)$ & $9(15)$ \\
\hline American eel & & $1(1)$ & & $1(1)$ & & $2(2)$ \\
\hline Blue catfish & $2(3)$ & $8(10)$ & $6(11)$ & $3(6)$ & $6(9)$ & $25(39)$ \\
\hline Channel catfish & $5(8)$ & $6(8)$ & $4(8)$ & $4(8)$ & $3(5)$ & $22(37)$ \\
\hline Flathead catfish & $2(3)$ & $4(5)$ & $3(6)$ & $3(6)$ & $2(3)$ & $14(23)$ \\
\hline River carpsucker & & & & $1(2)$ & & $1(2)$ \\
\hline Smallmouth buffalo & $1(2)$ & $1(1)$ & & & & $2(3)$ \\
\hline Shorthead redhorse & & & & & $1(2)$ & $1(2)$ \\
\hline Bluegill & $2(3)$ & & & & & $2(3)$ \\
\hline White bass & $1(2)$ & $1(1)$ & & & & $2(3)$ \\
\hline White crappie & $10(15)$ & & & $1(2)$ & & $11(17)$ \\
\hline Black crappie & $1(2)$ & & & & & $1(2)$ \\
\hline Freshwater drum & $2(3)$ & $4(5)$ & $6(11)$ & $3(6)$ & $3(5)$ & $18(30)$ \\
\hline Total species & 11 & 9 & 5 & 9 & 7 & 14 \\
\hline $\begin{array}{l}\text { Total numbers } \\
\text { (without revetment) }\end{array}$ & $31(49)$ & $28(35)$ & $20(38)$ & $14(27)$ & $17(28)$ & $\begin{array}{l}115(177) \\
{[98(149)]}\end{array}$ \\
\hline
\end{tabular}

* Description of reaches and bank types (= habitats) explained in text. ** Common and scientific names listed in Table 2.

$\dagger$ Catches presented as actual and (adjusted) numbers. Adjusted catches are scaled to a standard of 24 net-days. 
Table 13

Fish Collected by Hoop Nets from the Upstream* Reach of the Lower White River, Arkansas, Spring 1988

\begin{tabular}{|c|c|c|c|c|c|}
\hline Species** & $\begin{array}{l}\text { Mod.- } \\
\text { Slope } \\
\text { Bank } \\
\end{array}$ & $\begin{array}{c}\text { Sand- } \\
\text { bar }\end{array}$ & $\begin{array}{l}\text { Steep } \\
\text { Bank, } \\
\text { Cover } \\
\end{array}$ & $\begin{array}{c}\text { Steep } \\
\text { Bank, } \\
\text { No Cover } \\
\end{array}$ & Totalt \\
\hline Shovelnose sturgeon & & 1 & & & $1(1)$ \\
\hline Spotted gar & & & & $1(1)$ & $1(1)$ \\
\hline Longnose gar & 6 & & 1 & $2(3)$ & $9(10)$ \\
\hline Shortnose gar & 2 & 1 & 1 & $8(11)$ & $12(15)$ \\
\hline American eel & & & 1 & $2(3)$ & $3(4)$ \\
\hline Gizzard shad & & 3 & 1 & & $4(4)$ \\
\hline Blue catfish & 4 & 5 & 9 & $1(1)$ & $19(19)$ \\
\hline Channel catfish & 3 & 5 & 8 & $2(3)$ & $18(19)$ \\
\hline Flathead catfish & 2 & 3 & & $1(1)$ & $6(6)$ \\
\hline Bluegill & & 1 & 1 & $3(4)$ & $5(6)$ \\
\hline White bass & 2 & & 1 & $2(3)$ & $5(6)$ \\
\hline White crappie & 2 & & & $4(5)$ & $6(7)$ \\
\hline Black crappie & & & & $1(1)$ & $1(1)$ \\
\hline Freshwater drum & 11 & & 5 & $1(1)$ & $17(17)$ \\
\hline Total species & 8 & 7 & 9 & 12 & 14 \\
\hline Total numbers & 32 & 19 & 28 & $28(37)$ & $107(116)$ \\
\hline
\end{tabular}

* Description of reaches and bank types (= habitats) explained in text.

** Common and scientific names listed in Table 2.

$\dagger$ Catches presented as actual and (adjusted) numbers. Adjusted catches are scaled to a standard of 24 net-days. 
Table 14

Analysis of Variance* Results for Hoop Net Catches,

Lower White River Study

\begin{tabular}{|c|c|c|c|c|c|}
\hline $\begin{array}{c}\text { Source } \\
\text { of } \\
\text { Variation } \\
\end{array}$ & $\begin{array}{c}\begin{array}{c}\text { Sum } \\
\text { of } \\
\text { Squares }\end{array} \\
\end{array}$ & $\begin{array}{l}\text { Degrees } \\
\text { of } \\
\text { Freedom } \\
\end{array}$ & $\begin{array}{c}\text { Mean } \\
\text { Square } \\
\end{array}$ & F-Ratio & $\begin{array}{l}\text { Signi- } \\
\text { ficance } \\
\text { Level } \\
\end{array}$ \\
\hline Season & 0.0103 & 1 & 0.0103 & $<1$ & N.S.** \\
\hline Reach & 0.1286 & 1 & 0.1286 & 4.60 & $<0.05$ \\
\hline Habitat & 0.2388 & 3 & 0.0796 & 2.85 & $<0.05$ \\
\hline Season $\mathrm{X}$ reach & 0.0780 & 1 & 0.0780 & 2.79 & N.S. \\
\hline Season $\mathrm{X}$ habitat & 0.0491 & 3 & 0.0164 & $<1$ & N.S. \\
\hline Reach X habitat & 0.0249 & 3 & 0.0083 & $<1$ & N.S. \\
\hline $\begin{array}{l}\text { Season } X \text { reach } X \\
\text { habitat }\end{array}$ & 0.0958 & 3 & 0.0319 & 1.14 & N.S \\
\hline Error & 1.7900 & 64 & 0.0280 & & \\
\hline Total & 2.4155 & 79 & & & \\
\hline
\end{tabular}

* Three-way factorial, fixed effects ANOVA, $n=5$ observations per cell; data are catches per minute of electroshocking transformed as $10 \mathrm{l} 10$ $(y+1)$.

** N.S. = not significant. 
Table 15

Fish Collected by 30-Ft Seine from Two Reaches* of the

Lower White River, Arkansas, Fall 1987

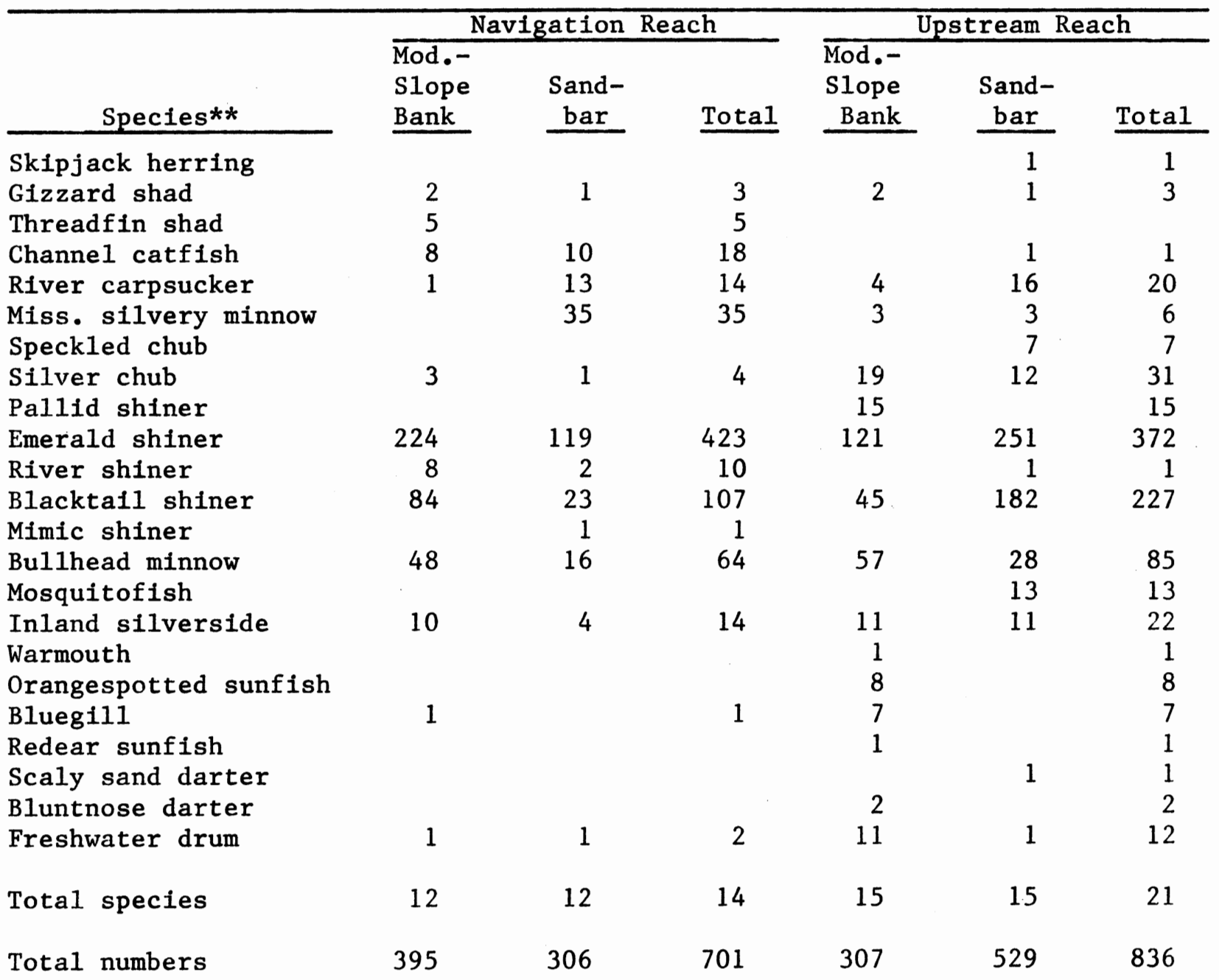

* Description of reaches and bank types (= habitats) explained in text. ** Common and scientific names listed in Table 2. 
Table 16

Fish Collected by 30-Ft Seine from Two Reaches* of the

Lower White River, Arkansas, Spring 1988

\begin{tabular}{|c|c|c|}
\hline Species** & $\begin{array}{c}\text { Navigation } \\
\text { Reach } \\
\text { Sandbar } \\
\end{array}$ & $\begin{array}{c}\text { Upstream } \\
\text { Reach } \\
\text { Sandbar } \\
\end{array}$ \\
\hline Gizzard shad & & 3 \\
\hline Threadfin shad & & 7 \\
\hline Channel catfish & 1 & \\
\hline River carpsucker & 4 & \\
\hline Cypress minnow & 1 & \\
\hline Miss. silvery minnow & 3 & 1 \\
\hline Speckled chub & & 4 \\
\hline Bigeye chub & & 1 \\
\hline Silver chub & 2 & \\
\hline Emerald shiner & 3 & 2 \\
\hline River shiner & 86 & 4 \\
\hline Pugnose minnow & 1 & 1 \\
\hline Silverband shiner & 14 & 10 \\
\hline Weed shiner & & 1 \\
\hline Blacktail shiner & 238 & 419 \\
\hline Mimic shiner & 61 & 26 \\
\hline Bullhead minnow & 71 & 113 \\
\hline Golden topminnow & & 1 \\
\hline Orangespotted sunfish & 5 & \\
\hline Bluegill & 8 & 2 \\
\hline Longear sunfish & 1 & 2 \\
\hline Largemouth bass & 4 & \\
\hline White crappie & 2 & \\
\hline Freshwater drum & 4 & 6 \\
\hline Total species & 18 & 17 \\
\hline Total numbers & 509 & 603 \\
\hline
\end{tabular}

* Description of reaches and bank types ( $=$ habitats) explained in text. ** Common and scientific names listed in Table 2. 
Table 17

Analysis of Variance Results for Seine Catches,

Lower White River Study

\begin{tabular}{|c|c|c|c|c|c|}
\hline $\begin{array}{c}\text { Source } \\
\text { of } \\
\text { Variation } \\
\end{array}$ & 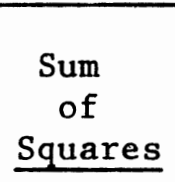 & $\begin{array}{l}\text { ANOVA T } \\
\text { Degrees } \\
\text { of } \\
\text { Freedom }\end{array}$ & $\begin{array}{c}\text { Mean } \\
\text { Square } \\
\end{array}$ & F-ratio & $\begin{array}{l}\text { Signi- } \\
\text { ficance } \\
\text { Level } \\
\end{array}$ \\
\hline Reach & 0.1523 & 1 & 0.1523 & 1.38 & N.S.** \\
\hline Habitat & 0.0036 & 1 & 0.0036 & $<1$ & N.S. \\
\hline Habitat $\mathrm{X}$ reach & 0.1237 & 1 & 0.1237 & 1.12 & N.S. \\
\hline Error & 2.2047 & 20 & 0.1102 & & \\
\hline \multicolumn{5}{|c|}{ ANOVA Table II } & \\
\hline Season & 0.2050 & 1 & 0.2050 & 1.73 & N.S. \\
\hline Reach & 0.2463 & 1 & 0.2463 & 2.08 & N.S. \\
\hline Season $\mathrm{X}$ reach & 0.0604 & 1 & 0.0604 & $<1$ & N.S. \\
\hline Error & 2.3673 & 20 & 0.1184 & & \\
\hline Total & 2.8790 & 23 & & & \\
\hline
\end{tabular}

* Three-way factorial, fixed effects ANOVA, $n=6$ observations per ce11; 1987 samples only; data are catches per 50-ft seine haul transformed as $\log 10(y+1)$.

** N.S. = not significant.

$\dagger$ Three-way factorial, fixed effects ANOVA, $n=6$ observations per ce11; 1987 and 1988 data for sandbar habitat only; data are catches per 50-ft seine haul transformed as $\log 10(y+1)$. 
Table 18

Condition Factors for Selected Species of Fish from Two Reaches of the Lower White River, Arkansas, Fall 1987

\begin{tabular}{|c|c|c|c|c|c|}
\hline \multirow[b]{2}{*}{ Species* } & \multirow[b]{2}{*}{ Reach } & \multirow[b]{2}{*}{$\underline{\mathrm{N}}$} & \multicolumn{3}{|c|}{ Condition Factor** } \\
\hline & & & Mean & $\begin{array}{l}\text { Standard } \\
\text { Deviation }\end{array}$ & $\begin{array}{c}\text { Coefficient } \\
\text { of } \\
\text { Variation } \\
(\%) \\
\end{array}$ \\
\hline \multirow[t]{2}{*}{$\begin{array}{l}\text { Freshwater } \\
\text { drum }\end{array}$} & $\begin{array}{r}\text { Entrance } \\
\text { channe1 }\end{array}$ & 77 & 1.11 & 0.20 & 18.0 \\
\hline & Upstream & 48 & 1.00 & 0.25 & 25.0 \\
\hline \multirow[t]{2}{*}{$\begin{array}{l}\text { Blue } \\
\text { catfish }\end{array}$} & $\begin{array}{r}\text { Entrance } \\
\text { channel }\end{array}$ & 25 & 0.82 & 0.21 & 26.0 \\
\hline & Upstream & 4 & 0.73 & 0.09 & 12.8 \\
\hline \multirow[t]{2}{*}{$\begin{array}{l}\text { Channel } \\
\text { catfish }\end{array}$} & $\begin{array}{r}\text { Entrance } \\
\text { channel }\end{array}$ & 7 & 0.89 & 0.15 & 17.2 \\
\hline & Upstream & 5 & 0.78 & 0.12 & 15.3 \\
\hline \multirow[t]{2}{*}{$\begin{array}{l}\text { Flathead } \\
\text { catfish }\end{array}$} & $\begin{array}{r}\text { Entrance } \\
\text { channel }\end{array}$ & 23 & 0.93 & 0.13 & 14.5 \\
\hline & Upstream & 4 & 0.90 & 0.12 & 13.7 \\
\hline \multirow[t]{2}{*}{$\begin{array}{c}\text { White } \\
\text { bass }\end{array}$} & $\begin{array}{r}\text { Entrance } \\
\text { channel }\end{array}$ & 7 & 1.15 & 0.06 & 5.3 \\
\hline & Upstream & -4 & 1.13 & 0.02 & 1.7 \\
\hline \multirow[t]{2}{*}{$\begin{array}{l}\text { Smallmouth } \\
\text { buffalo }\end{array}$} & $\begin{array}{r}\text { Entrance } \\
\text { channel }\end{array}$ & 10 & 1.48 & 0.29 & 19.9 \\
\hline & Upstream & 5 & 1.51 & 0.14 & 9.1 \\
\hline
\end{tabular}

* Common and scientific names shown in Table 2.

** Computed as Weight $\times 10^{5}$ divided by the Length cubed (Ricker 1975).

$\dagger \mathrm{N}=$ sample size. 
Table 19

Summary of Fish Detections from Acoustic Echograms, Estimates of

Relative Fish Density, and Test Results Regarding Differences

Among Sampling Periods and River Reaches,

Lower White River Arkansas, Arkansas

\begin{tabular}{|c|c|c|c|c|c|}
\hline & River & No. & Total & $\operatorname{Rel}$ & ensity* \\
\hline Month & Reach & Transects & Fish & $\overline{\text { Mean }}$ & S.E.** \\
\hline May & Upstream & 46 & 41 & 1.5 & 0.30 \\
\hline May & Entrance Channe1 & 59 & 73 & 1.4 & 0.20 \\
\hline Sep & Upstream & 59 & 105 & 3.3 & 0.62 \\
\hline Sep & Entrance Channel & 59 & 104 & 3.7 & 0.78 \\
\hline Overall & & 223 & 323 & 2.5 & 0.26 \\
\hline
\end{tabular}

Analysis of Means (ANOVA)

\begin{tabular}{lcccc}
$\begin{array}{c}\text { Source } \\
\text { of } \\
\text { Variation }\end{array}$ & $\begin{array}{c}\text { Degrees } \\
\text { of } \\
\text { Freedom }\end{array}$ & $\begin{array}{c}\text { Mean } \\
\text { Square }\end{array}$ & F-Ratio & $\begin{array}{c}\text { Significance } \\
\text { Level }\end{array}$ \\
\cline { 2 - 3 } & 1 & 231.1 & 13.64 & 0.000 \\
Meach & 1 & 1.3 & 0.06 & 0.807 \\
Month X reach & 1 & 3.5 & 0.21 & 0.649 \\
Error & 222 & 16.9 & &
\end{tabular}

* An index to the density of fish per surface area of water.

** S.E. = standard error. 
Table 20

Acoustic Size Summary of Fish Echoes Detected in Hydroacoustic Sampling, Minimum Size Processed Set to Approximately $-58.5 \mathrm{~dB}$

\begin{tabular}{|c|c|c|c|c|c|c|c|c|}
\hline \multirow[b]{2}{*}{ Month } & \multirow{2}{*}{$\begin{array}{l}\text { River } \\
\text { Reach }\end{array}$} & \multirow{2}{*}{$\begin{array}{c}\text { No. } \\
\text { Echoes } \\
\end{array}$} & \multicolumn{3}{|c|}{ Acoustic Size, $\mathrm{dB}$} & \multicolumn{3}{|c|}{ Approx. Size, $\mathrm{cm}^{*}$} \\
\hline & & & Min & $\operatorname{Max}$ & Mean & Min & Max & Mean \\
\hline May & Upstream & 26 & -57.9 & $-24 \cdot 7$ & -44.5 & 2 & 122 & 11 \\
\hline May & Navigation & 37 & -58.4 & -23.9 & -48.1 & 2 & 134 & 7 \\
\hline Sep & Upstream & 80 & -57.0 & -26.0 & -43.0 & 3 & 104 & 14 \\
\hline Sep & Navigation & 88 & -58.3 & -26.3 & -46.0 & 2 & 100 & 9 \\
\hline Ove & & 231 & -58.4 & -23.9 & -45.1 & 2 & 134 & 11 \\
\hline
\end{tabular}

* Rough guide to fish sizes in centimetres based on target strength to length conversion equation by Love (1971). Centimetre sizes should be treated as an index to fish lengths. 
Table 21

Species of Fish Possibly Occurring Within the Lower White River, Arkansas

\begin{tabular}{|c|c|c|c|c|}
\hline Family Species & $\begin{array}{l}\text { Resi- } \\
\text { dence* }\end{array}$ & $\begin{array}{c}\text { Major } \\
\text { Habitat** }\end{array}$ & $\begin{array}{l}\text { Migra- } \\
\text { tory? }\end{array}$ & Statustt \\
\hline $\begin{array}{l}\text { Petromyzontidae } \\
\text { Chestnut lamprey (Ichthyomyzon } \\
\quad \text { castaneus) }\end{array}$ & $\mathrm{R}$ & & $\mathrm{Y}$ & C \\
\hline $\begin{array}{l}\text { Acipenseridae } \\
\text { Lake sturgeon (Acipenser fulvescens) } \\
\text { Pallid sturgeon (Scaphirhynchus } \\
\text { albus) } \\
\text { Shovelnose sturgeon (S. platorynchus) }\end{array}$ & $\begin{array}{l}\mathrm{T} \\
\mathrm{R}\end{array}$ & M & $\begin{array}{l}\mathrm{Y} ? \\
\mathrm{Y} ?\end{array}$ & $\begin{array}{l}\mathrm{R} ? \\
\mathrm{C}\end{array}$ \\
\hline $\begin{array}{l}\text { Polyodontidae } \\
\text { Paddlefish (Polyodon spathula) }\end{array}$ & $\mathrm{T} ?$ & M & $\mathrm{Y}$ & $\mathrm{U} ?$ \\
\hline $\begin{array}{l}\text { Lepisosteidae } \\
\text { Spotted gar (Lepisosteus oculatus) } \\
\text { Longnose gar (L. osseus) } \\
\text { Shortnose gar (L. platostomus) } \\
\text { Alligator gar (L. spatula) }\end{array}$ & $\begin{array}{l}\mathrm{T} \\
\mathrm{R} \\
\mathrm{R} \\
\mathrm{T}\end{array}$ & M & $\begin{array}{l}\mathrm{N} \\
\mathrm{N} \\
\mathrm{N} \\
\mathrm{N}\end{array}$ & $\begin{array}{l}\text { U } \\
\text { A } \\
\text { A } \\
\text { R }\end{array}$ \\
\hline $\begin{array}{l}\text { Amiidae } \\
\quad \text { Bowfin (Amia calva) }\end{array}$ & R & & $\mathrm{N}$ & $\mathrm{C}$ \\
\hline $\begin{array}{l}\text { Anguillidae } \\
\text { American eel (Anguilla rostrata) }\end{array}$ & $\mathrm{R}$ & & $\mathrm{Y}$ & $\mathrm{C}$ \\
\hline $\begin{array}{l}\text { Clupeidae } \\
\text { Alabama shad (Alosa alabamae) } \\
\text { Skipjack herring (Alosa } \\
\text { chrysochloris) } \\
\text { Gizzard shad (Dorosoma cepedianum) } \\
\text { Threadfin shad (D. petenense) }\end{array}$ & $\begin{array}{l}\mathrm{R} \\
\mathrm{R} \\
\mathrm{R}\end{array}$ & M & $\begin{array}{l}\mathrm{Y} \\
\mathrm{N} \\
\mathrm{N}\end{array}$ & $\begin{array}{l}\text { C } \\
\text { A } \\
\text { A }\end{array}$ \\
\hline $\begin{array}{l}\text { Hiodontidae } \\
\text { Goldeye (Hiodon alosoides) } \\
\text { Mooneye (H. tergisus) }\end{array}$ & $\begin{array}{l}R \\
R\end{array}$ & & $\begin{array}{l}\mathrm{N} \\
\mathrm{Y}\end{array}$ & $\begin{array}{l}\mathrm{C} \\
\mathrm{R} ?\end{array}$ \\
\hline
\end{tabular}

(Continued)

\footnotetext{
* Residence: $R$ = resident of lower White River proper; $T$ = transient in study area.

** Major Habitat (if transient): $F=$ lower White River floodplain; $T=$ regular invader from tributaries; $M=$ Mississippi River.

$\dagger$ Migratory?: $Y$ = yes; migrants may be residents that move farther upstream or species moving through from Mississippi River.

It Status: $R=$ rare; $U=$ uncommon; $C=$ common; $A=$ abundant. Question mark indicates uncertainty of classification.
} 
Table 21 (Continued)

\begin{tabular}{|c|c|c|c|c|}
\hline Family Species & $\begin{array}{l}\text { Resi- } \\
\text { dence* }\end{array}$ & $\begin{array}{c}\text { Major } \\
\text { Habitat** }\end{array}$ & $\begin{array}{l}\text { Migra- } \\
\text { tory?t }\end{array}$ & Status H \\
\hline \multicolumn{5}{|l|}{ Esocidae } \\
\hline Grass pickerel (Esox cmericanus) & $\mathrm{T}$ & F & $\mathrm{N}$ & $\mathrm{U}$ \\
\hline Chain pickerel (E. niger) & $\mathrm{T}$ & $\mathbf{F}$ & $\mathrm{N}$ & $\mathrm{U}$ \\
\hline \multicolumn{5}{|l|}{ Cyprinidae } \\
\hline Common carp (Cyprinus carpio) & $\mathbf{R}$ & & $\mathrm{Y}$ & A \\
\hline $\begin{array}{l}\text { Grass carp (Ctenopharyngodon idella) } \\
\text { W. silvery minnow (Hybognathus }\end{array}$ & $\mathrm{T} ?$ & M & $\mathrm{N}$ ? & $\mathrm{U} ?$ \\
\hline argyritis) & $\mathrm{T}$ & M & $\mathrm{N}$ ? & $\mathbf{R}$ \\
\hline Cypress minnow ( $H$. hayi) & $\mathrm{T}$ & $\mathrm{F}$ & $\mathrm{N}$ & $\mathrm{R}$ \\
\hline Central silvery minnow (H. nuchalis) & $\mathbf{R}$ & & $\mathrm{N}$ & A \\
\hline Plains minnow (H. placitus) & $\mathrm{T}$ & M & $\mathrm{N}$ & $\mathrm{R}$ \\
\hline Speckled chub (Hybopsis aestivalis) & $\mathbf{R}$ & & $\mathrm{N}$ & C \\
\hline Bigeye chub (H. amblops) & $\mathbf{R}$ & & $\mathrm{N}$ & $\mathrm{U}$ \\
\hline Sturgeon chub (H. gelida) & $\mathrm{T}$ & M & $\mathrm{N}$ & $\mathbf{R}$ \\
\hline Flathead chub (H. gracilis) & $\mathbf{T}$ & M & $\mathrm{N}$ & $\mathbf{R}$ \\
\hline Sicklefin chub ( $H$. meeki) & $\mathrm{T}$ & M & $\mathbf{N}$ & $\mathbf{R}$ \\
\hline Silver chub (H. storeriana) & $\mathbf{R}$ & & $\mathrm{N}$ & $\mathrm{C}$ \\
\hline \multicolumn{5}{|l|}{ Golden shiner (Notemigonus } \\
\hline crysocleucas) & $\mathbf{R}$ & & $\mathrm{N}$ & $\mathrm{U}$ \\
\hline Pallid shiner (Notropis amnis) & $\mathrm{R}$ ? & & $\mathrm{N}$ & $\mathrm{U}$ ? \\
\hline Emerald shiner (N. atherinoides) & $\mathbf{R}$ & & $\mathrm{N}$ & A \\
\hline River shiner (N. blennius) & $\mathbf{R}$ ? & & $\mathrm{N}$ & $\mathrm{U}$ \\
\hline Ghost shiner (N. buchanani) & $\mathbf{R}$ ? & & $\mathrm{N}$ & $\mathrm{U}$ \\
\hline Pugnose minnow (N. emiliae) & $\mathrm{T}$ & $\mathrm{F}$ & $\mathrm{N}$ & $\mathrm{U}$ \\
\hline Ribbon shiner ( $N$. fumeus) & $\mathrm{T}$ ? & $\mathrm{T}$ & $\mathrm{N}$ & $\mathrm{U}$ \\
\hline Red shiner (N. Zutrensis) & $\mathrm{T}$ & $\mathrm{T}$ & $\mathrm{N}$ & $\mathrm{U}$ \\
\hline Taillight shiner (N. maculatus) & $\mathrm{T}$ & F & $\mathrm{N}$ & $\mathrm{R}$ \\
\hline Silverband shiner (N. shumardi) & $\mathrm{T}$ ? & M & $\mathrm{N}$ & $\mathrm{U}$ \\
\hline Weed shiner (N. texanus) & $\mathrm{T}$ & $\mathrm{T}$ & $\mathrm{N}$ & $\mathrm{U}$ \\
\hline Blacktail shiner (N. venustus) & $\mathbf{R}$ & & $\mathrm{N}$ & $\mathrm{C}$ \\
\hline Mimic shiner ( $N$. volucellus) & $\mathbf{R}$ & & $\mathrm{N}$ & C \\
\hline Bullhead minnow (Pimephales vigilax) & & & $\mathrm{N}$ & \\
\hline \multicolumn{5}{|l|}{ Catostomidae } \\
\hline Blue sucker (Cycleptus elongatus) & $\mathrm{T}$ & M & $\mathrm{Y}$ & $\mathrm{U}$ \\
\hline River carpsucker (Carpiodes carpio) & $\mathrm{R}$ & & $\mathrm{N}$ & $\mathrm{C}$ \\
\hline Quillback (C. cyprinus) & $\mathrm{T}$ ? & M? & $\mathrm{N}$ ? & $\mathbf{R}$ \\
\hline Highfin carpsucker (C. velifer) & $\mathrm{T} ?$ & M? & $\mathrm{N} ?$ & $\mathrm{R}$ \\
\hline Smallmouth buffalo (Ictiobus bubalus) & $\mathrm{R}$ & & $\mathrm{Y}$ & A \\
\hline Bigmouth buffalo (I. cyprinellus) & $\mathbf{R}$ & & $\mathrm{Y}$ & $\mathrm{C}$ \\
\hline Black buffalo (I. niger) & $\mathbf{R}$ & & $\mathrm{Y}$ & $\mathrm{U}$ \\
\hline Spotted sucker (Minytrema melanops) & $\mathrm{T} ?$ & $\mathrm{~F}, \mathrm{~T}$ & $\mathrm{~N}$ & $\mathbf{R}$ \\
\hline $\begin{array}{l}\text { Shorthead redhorse (Moxostoma } \\
\text { macrolepidotum) }\end{array}$ & & & & \\
\hline & R? & & Y? & $\mathbf{R}$ \\
\hline
\end{tabular}

(Continued) 
Table 21 (Continued)

\begin{tabular}{|c|c|c|c|c|}
\hline Family Species & $\begin{array}{l}\text { Resi- } \\
\text { dence* }\end{array}$ & $\begin{array}{c}\text { Major } \\
\text { Habitat** } \\
\end{array}$ & $\begin{array}{l}\text { Migra- } \\
\text { tory?t } \\
\end{array}$ & Statust† \\
\hline $\begin{array}{l}\text { Ictaluridae } \\
\text { Blue catfish (Ictalums furcatus) } \\
\text { Black bullhead (I. melas) } \\
\text { Yellow bullhead (I. natalis) } \\
\text { Brown bullhead (I. nebulosus) } \\
\text { Channel catfish (I. punctatus) } \\
\text { Stonecat (Noturus flavus) } \\
\text { Tadpole madtom (N. gyrinus) } \\
\text { Flathead catfish (Pylodictis } \\
\text { olivaris) }\end{array}$ & $\begin{array}{l}\mathrm{R} \\
\mathrm{T} \\
\mathrm{T} \\
\mathrm{T} \\
\mathrm{R} \\
\mathrm{T} \\
\mathrm{T}\end{array}$ & $\begin{array}{l}\mathrm{T} \\
\mathrm{F}, \mathrm{T} \\
\mathrm{F} \\
\mathrm{M} ? \\
\mathrm{~T}\end{array}$ & $\begin{array}{l}\mathrm{Y} ? \\
\mathrm{~N} \\
\mathrm{~N} \\
\mathrm{~N} \\
\mathrm{Y} ? \\
\mathrm{~N} \\
\mathrm{~N}\end{array}$ & $\begin{array}{l}A \\
R \\
R \\
R \\
A \\
R \\
C\end{array}$ \\
\hline $\begin{array}{l}\text { Aphredoderidae } \\
\text { Pirate perch (Aphredoderus sayanus) }\end{array}$ & $\mathrm{T}$ & $\mathrm{F}$ & $\mathrm{N}$ & $\mathrm{R}$ \\
\hline $\begin{array}{l}\text { Cyprinodontidae } \\
\text { Golden topminnow (Fundulus } \\
\text { chrysotus) } \\
\text { Blackstripe topminnow (F. notatus) } \\
\text { Blackspotted topminnow (F. } \\
\text { olivaceus) }\end{array}$ & $\begin{array}{l}\mathrm{T} \\
\mathrm{R} ? \\
\mathrm{R} ?\end{array}$ & $F$ & $\begin{array}{l}\mathrm{N} \\
\mathrm{N}\end{array}$ & $\begin{array}{l}\mathrm{R} \\
\mathrm{U}\end{array}$ \\
\hline $\begin{array}{l}\text { Poeciliidae } \\
\qquad \text { Mosquitofish (Gambusia affinis) }\end{array}$ & $\mathrm{R}$ & & $\mathrm{N}$ & C \\
\hline $\begin{array}{l}\text { Atherinidae } \\
\text { Brook silverside } \\
\text { (Labidesthes sicculus) } \\
\text { Inland silverside (Menidia } \\
\text { beryllina) }\end{array}$ & $\mathrm{R}$ & $\mathrm{F}, \mathrm{T}$ & N & $\mathrm{U}$ \\
\hline $\begin{array}{l}\text { Percichthyidae } \\
\text { White bass (Morone crysops) } \\
\text { Yellow bass (M. mississippiensis) } \\
\text { Striped bass (M. saxatiZis) }\end{array}$ & $\begin{array}{l}\mathrm{R} \\
\mathrm{R} ? \\
\mathrm{~T} ?\end{array}$ & & $\begin{array}{l}\mathrm{Y} \\
\mathrm{Y} \\
\mathrm{Y}\end{array}$ & $\begin{array}{l}\mathrm{C} \\
\mathrm{U} \\
\mathrm{U}\end{array}$ \\
\hline $\begin{array}{l}\text { Centrarchidae } \\
\text { Flier (Centrarchus macropterus) } \\
\text { Banded pygmy sunfish (Elassoma } \\
\text { zonatum) } \\
\text { Green sunfish (Lepomis cyanellus) } \\
\text { Warmouth (L. gulosus) } \\
\text { Orangespotted sunfish (L. humilis) } \\
\text { Bluegill (L. macrochirus) } \\
\text { Redear sunfish ( } L . \text { microlophus) } \\
\text { Longear sunfish ( } L \text {. megalotis } \\
\text { Spotted sunfish ( } L \text {. punctatus) }\end{array}$ & $\begin{array}{l}\mathrm{T} \\
\\
\mathrm{T} \\
\mathrm{R} ? \\
\mathrm{R} \\
\mathrm{R} \\
\mathrm{R} \\
\mathrm{R} ? \\
\mathrm{R} \\
\mathrm{T}\end{array}$ & F & $\begin{array}{l}\text { N } \\
\text { N } \\
N \\
N \\
N \\
N \\
N \\
N \\
N \\
N\end{array}$ & $\begin{array}{l}R \\
\mathrm{U} \\
\mathrm{U} \\
\mathrm{U} \\
\mathrm{C} \\
\mathrm{U} \\
\mathrm{C} \\
\mathrm{R}\end{array}$ \\
\hline
\end{tabular}

(Continued)

(Sheet 3 of 4 ) 
Table 21 (Concluded)

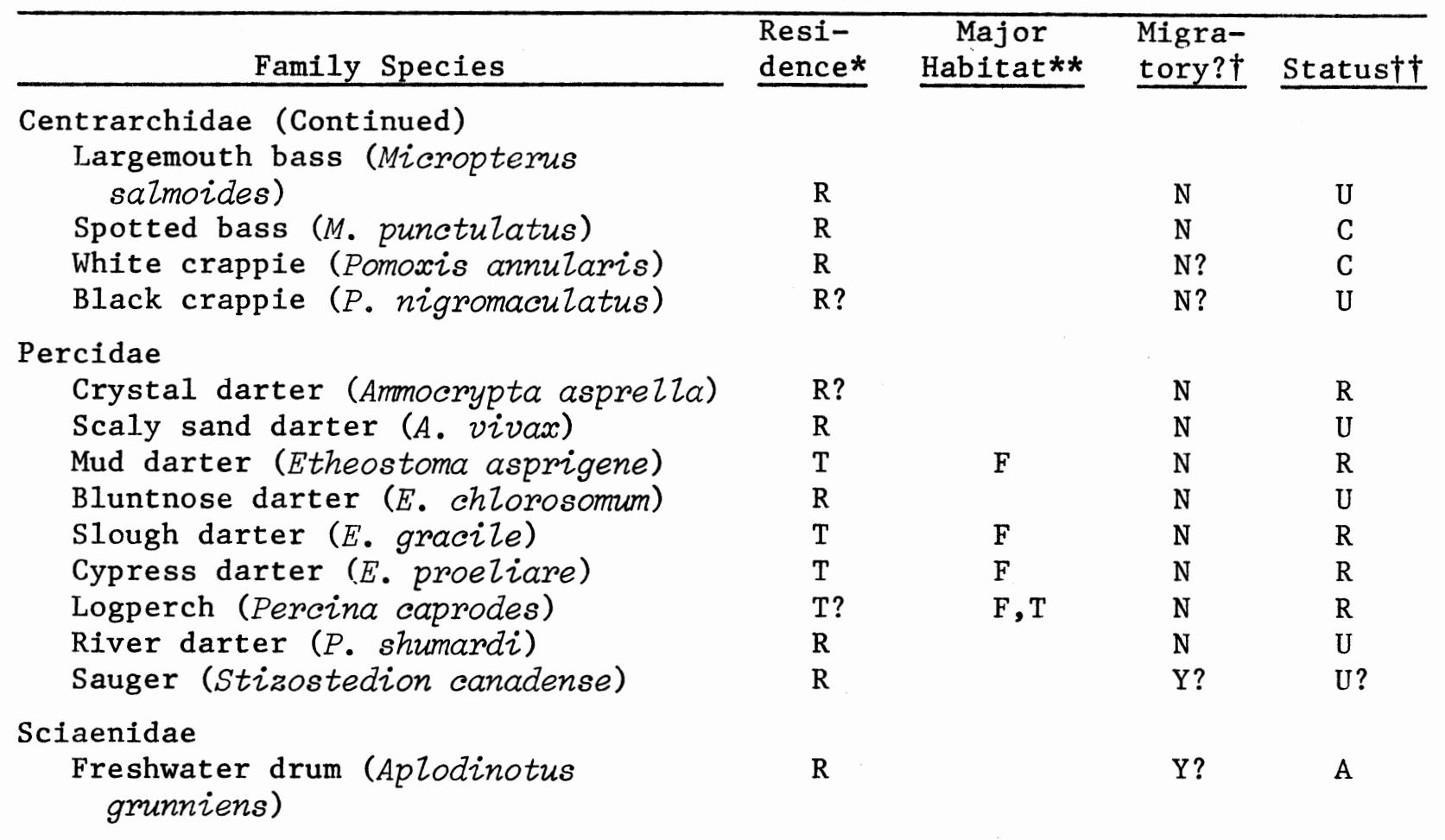


